\title{
Physiological Ecology of the Deposit-Feeding Sea Star Ctenodiscus crispatus: Ciliated Surfaces and Animal-Sediment Interactions
}

\author{
J. Malcolm Shick, Kelly C. Edwards and John H. Dearborn \\ Department of Zoology, University of Maine, Orono, Maine 04469 , USA
}

\begin{abstract}
Ctenodiscus crispatus is a non-selective deposit feeder on organically-rich $19.7 \%$ of sediment dry weight) oxidized clayey-silt in the Gulf of Maine, USA. The mud star's lack of selectivity is attributed to the thorough mixing and very fine particle size of the habitat sediment, in which $90 \%$ of the particle's dre less than $4 \Phi(62.5 \mu \mathrm{m})$ in diameter These sediments are easily disturbed and present problems in maintaining unimpared gas-exchange surfaces. C. crispatus has adapted to this by establishing a temporary burrow and using its extensible epiproctal cone to maintain connection with the water column. The burrow is irrigated by ciliary currents which, based on laboratory observations of burrowed mud stars, provide a continuous respiratory flow with a minumum of disturbance to the flocculent surface sediment. Particles incidentally drawn into the burrow are trapped in cleansing mucus which is ingested, likely accounting for the enrichment in organic content of stomach contents relative to habitat sediment. The low convection requirement $\left(1.69\right.$ l of water pumped per $\mathrm{ml}$ of $\mathrm{O}_{2}$ removed from the current) reflects the respiratory, as opposed to nutritional, nature of the current. The cribriform organs not only create the driving force for the ruspiratory current, but themselves provide a large surface area $\left(11 \mathrm{~cm}^{2}\right.$ in a $1.5 \mathrm{~g}$ individua!), and additionally are richly supplied with microvilli. Both the extensive culiation and anatomical arrangenuent of the cribriform lamellae eliminate unstirred layers at their surface and account for low $K$, values for dissolved amino acid uptake, which despite a low concentration (average $4.4 \mathrm{uM}$ ) in interstitial water in the habitat provide a net income in the animal's encrgy budget. The biology of the eurybathic $C$. crispatus is discussed with reference to that of the related Porcullanasteridae, a group of truly deep-sea deposit feeding asterolds.
\end{abstract}

\section{INTRODUCTION}

The mud star Ctenodiscus crispatus (Retzius) is a small, circumboreal goniopectinid asteroid common on level mud bottoms throughout the Gulf of Maine. Generally considered to be a boreo-arctic species, the mud star is also found as far south as Cape Hatteras on the eastern North American coast (Verrill, 1914), and south to Panama on the western coast (Grainger, 1966). The bathymetric range is from 2 to at least $1900 \mathrm{~m}$ (Alton, 1966; Grainger, 1966), and most specimens are found at depths of 50-600 m (Mortensen, 1927). More southern populations occur in deeper water than northern populations. The mud star may be locally abundant and form a significant portion of the macroinvertebrate biomass in clayey silt substrates.

Previous work on the mud star has concentrated on anatomy and morphology (Fisher, 1911; Verrill, 1914;
Lieberkind, 1935; Madsen, 1961a; Tumer and Dearborn, 1972). Gislén (1924) observed the general patterns of ciliation of Ctenodiscus crispatus. Sperm morphology has been examined by Summers et al. (1975). Sterols in this asteroid have been characterized by Grossert et al. (1973). Turner (1976) noted the effect of the ovarian hormone 1-methyladenine on spawning in this species. Shick (1976) described the respiratory and behavioral responses of this infaunal sea star to hypoxia and hydrogen sulfide. Finally, reproduction and population genetics of C. crispatus have been studied by Shick et al. (in press).

Other than the general observation that the mud star is an infaunal deposit feeder, little is known of its feeding biology. On the basis of a simple experiment carried out during his studies on the ciliation of various echinoderms, Gislén (1924) concluded that Ctenodiscus crispatus is probably a ciliary-mucoid feeder on 
sediment particles. Fie believed that the ciliated lamellae on the cribriform organs, which occur between all marginal plates in this species, are used as particle sorting devices in addition to producing respiratory currents. Later authors have generally relied on Gislén's (1924) account (e.g. Flyman, 1955; Madsen, 1961a). In its feering habits and general morphology C. crispatus is similar to the deep-sea Porcellanasteridae, and Madsen (1961a) implies that it may represent an evolutionary step in their development. Earlier workers, in fact, placed Ctenodiscus in the Porcellanasteridae (see Mortensen, 1927) although Spencer and Wright (1966) accept its placement in the Goniopectinidae.

The functions of the cribriform organs and associated channels, cilia, tube feet, and mucus in Ctenodiscus crispatus have not been examined in sufficient detail to explain the mechanisms of feeding and burrow irrigation in this animal which lives in unstable sediments of very fine particle size. The functional morphology of $C$. crispatus is of interest because of its manipulation of sediment, both physically and chemically. Organism-sediment relations in fine-grained deposits have been reviewed by Rhoads (1974) who emphasized the importance of activities of mud-dwelling animals in modifying the physical and chemical properties of the sea floor. Because of the close similarities in morphology and feeding habits between C. crispatus and the porcellanasterids, many aspects of the biology of the mud star may be applicable to these deep-sea forms as well.

\section{MATERIALS AND METHODS}

\section{Sample Collections}

Numerous specimens of Ctenodiscus crispatus, a total of 112 environmental sediment samples, and 52 sediment samples removed from the cardiac stomachs of individual sea stars were obtained in the Gult of Maine, USA, during 13 trips at various seasons from 1977 to 1.980 . The collecting site $143^{\circ} 44^{\prime} 12^{\prime \prime} \mathrm{N}$, $69^{\circ} 39^{\prime} 21^{\prime \prime} \mathrm{W}$ to $43^{\circ} 43^{\prime} 18^{\prime \prime} \mathrm{N}, 69^{\circ} 39^{\prime} 48^{\prime \prime} \mathrm{W}$ ) was located off Damariscove Island and The Cuckolds, Maine, about $10 \mathrm{~km}$ offshore from the mouth of the Damariscotta River at a depth of $60-76 \mathrm{~m}$. The bottom at the site was a gently seaward-sloping basin of soft silt and clay with occasional rock outcrops. Bottom temperatures ranged from $2.8^{\circ} \mathrm{C}$ (28 March 1979) to $9.4^{\circ} \mathrm{C}$ (29 November 1977) (see Edwards, 1980 for sampling details)

Environmental sediments were taken with a Shipek grab (Holme, 1964). Subsamples of grabs in which the sediment surface was undisturbed were taken with suction corers made from glass or plastic hypodermic syringes and were maintained on ice during transport to the laboratory. Core lengths were generally about $5 \mathrm{~cm}$.

Specimens were usually taken in a Blake (beamtype) trawl containing a $3 \mathrm{~mm}$ stretch-mesh bag liner Juvenile sea stars were obtained by gently sieving the sediment retained by the trawl through a $1 \mathrm{~mm}$ mesh. Aduits and juvenules for physiological studies were immediately placed in sea water at $0^{\circ}-2^{\circ} \mathrm{C}$ for transport to the laboratory, where they were maintained in recirculating seawater at seasonal habitat temperatures. A few mud stars were captured in grab samples. These specimens were important because direct comparisons could be made between ingested sediment removed from the sea stars and the environmental sediment immediately surrounding them. Sediment from mud star stomachs was extruded by applying gentle pressure on the aboral surface.

\section{Sediment Analyses}

Some cores were analyzed as entire samples. Others were split lengthwise to provide subsamples for separate determinations of organic content and particle size. A few cores were divided into several contiguous depth horizons of 0-2 $\mathrm{mm}, 2-7 \mathrm{~mm}, 7-12 \mathrm{~mm}$, and 12-22 mm, to check for variation with sediment depth.

Organic content and particle size distribution were determined for sediment from both the environment and the stomachs of selected mud stars. Weights for all procedures were determined to the nearest $10 \mu \mathrm{g}$. An estimate of total organic matter (TOM) was determined by loss of weight of dried sediment on ignition at $500^{\circ} \mathrm{C}$ for $4 \mathrm{~h}$ (Byers et al., 1978). No correction for carbonate content, which is very low in these sediments (L. M. Mayer, pers. comm.), was made

Particle size distributions were determined using a combination of wet sieving and Coulter Counter analysis. Each sample was washed through stacked sieves of $500,250,125$, and $75 \mu \mathrm{m}$. Fractions $>75 \mu \mathrm{m}$ were dried, weighed, and the percentage of total dry sample weight calculated. The $<75 \mu \mathrm{m}$ fraction was analyzed with a particle counter (Model TA Coulter Counter) with a $200 \mu \mathrm{m}$ aperture following the general procedures of Sheldon and Parsons (1967). The $200 \mu \mathrm{m}$ aperture allows accurate analysis to the $4 \mu \mathrm{m}$ level. Data were transformed from micrometers to $\Phi$ (phi) units, the most accepted grade scale in recent sedimentological work (Folk, 1974). A number of random samples were examined visually to categorize particle species present in each size range.

The arcsine transformation test for the equality of two percentages (Sokal and Rohlf, 1969) was used to 
compare TOM content between mud star stomach and environmental sediment samples. Particle size distribution plots of environmental and asterond sediment samples were prepared using a modified computer plotting program for the Calcomp plotter. Analysis of differences between various particle size distributions was carried out by discriminant analysis (Sokal and Rohlf, 1969)

Oxidation-reduction potential (redox, Eh) profiles were determined with a polished platinum electrode at $5 \mathrm{~mm}$ intervals in $50 \mathrm{cc}$ glass syringe cores placed in seawater aquaria at the prevailing seabed temperature $\left(5^{\circ}-8^{\circ} \mathrm{C}\right)$; corrections were made for the calomel electrode (Orion Research) potential at the experimental temperature.

\section{Electron Microscopy}

Scanning electron microscopy (SEM) and transmission electron microscopy (TEM) were used to study morphological details of mud stars. All specimens were initially fixed aboard the collecting vessel, either in chilled $2.5 \%$ phosphate-buffered glutaraldehyde for $2 \mathrm{~h}$ (most SEM specimens) (Sabatinı et al., 1963), or in $2 \%$ glutaraldehyde in $77 \%$ seawater for $12 \mathrm{~h}$ (some SEM and all TEM specimens) (Holland and Jesperson, 1973). All specimens were subsequently washed and stored in cold 0.1 M Sorenson's phosphate buffer Secondary fixation of all material was in cold $2 \%$ osmium tetroxide. The best SEM results were obtained on specimens dehydrated in ethanol series, critical point dried, and coated with a gold/palladium mixture. Full details are given in Edwards (1980).

\section{Dissolved Primary Amines}

Interstitial water was expressed from fresh sediment under $\mathrm{N}_{2}$ pressure (25-40 psi) in a stainless steel Millipore pressure filtration apparatus fitted with acidrinsed filters $(0.22 \mu n$ pore size) Total primary amine concentration was determined with Fluorescamine reagent (Roche Diagnostics) in a Turner Model 110 fluorometer using the methods of North (1975) and Stephens (1975). Glycine standards in artificial seawater (formulation of the Marine Biological Laboratory; Cavanaugh, 1956) were employed.

The uptake of primary amines from $10-15 \mathrm{ml}$ of interstitial water obtained as above was monitored fluorometrically in juvenile Ctenodiscus crispatus. All specimens were rinsed of surface sediment and incubated in an antibiotic solution $(500,000$ units penicillin, $200 \mathrm{mg}$ streptomycin sulfate, and $50 \mathrm{mg}$ chloramphenicol per liter of artificial seawater) for $24 \mathrm{~h}$ prior to, and rinsed in clean artificial seawater immediately before, the experjments. Parallel studies were performed in which antibiotic-treated juveniles were exposed to uniformly labeled ${ }^{4} \mathrm{C}$-glycine (New England Nuclear) in $32 \%$ S artificial seawater and medium glycine concentration was simultaneously measured by liquid scintillation and fluorometric techniques. Neither primary amine nor radioactivity levels in control vessels containing no mud stars changed during $18 \mathrm{~h}$ at $8{ }^{\circ} \mathrm{C}$. Finally, the kinetıcs of uptake of ${ }^{14} \mathrm{C}$-glycine by individual juveniles were determined using concentrations ranging from 1.9 to $101.3 \mu \mathrm{M}$ in artificial seawater and incubation times of $10 \mathrm{~min}$. Specimens were then quickly rinsed in icecold artificial seawater, blotted dry, weighed, digested overnight in Protosol tissue solubilizer (New England Nuclear), and subsequently assayed for total glycine uptake on a Packard Model 3255 liquid scintillation counter. Corrections for quenching were made using internal and external standards. Similar kinetic experiments were conducted with ${ }^{14} \mathrm{C}$-asparate, both in the absence and presence of $100 \mu \mathrm{M}$ glycine. All uptake experiments were performed at $8^{\circ} \mathrm{C}$. Additional specimens wore used to determine the relationship between blotted wet and dry weight.

\section{Oxygen Uptake}

Rates of oxygen uptake by intact mud stars were monitored continuously in closed vessels described in Shick (1976) at $5^{\circ}$ or $8^{\circ} \mathrm{C}$ using Yellow Springs Instrument Company Models 5720 or 5750 oxygen probes and a Model 54ARC oxygen meter. Oxygen uptake rates by some juveniles were measured with an oxygen microelectrode (Rank Brothers). Sediment collected from the mud stars' habitat was sieved to remove macrofauna, frozen and thawed to kill other organisms, and then placed in $11 \mathrm{~cm}$ diameter glass bowls to a depth of $4 \mathrm{~cm}$. Animals were allowed to establish burrows in these bowls of sediment which were submerged in recirculating aquaria at $5^{\circ} \mathrm{C}$. Water samples (50-75 $\mu 1)$ taken from distinct excurrent channels of individual mud star burrows using a glass syringe fitted with a drawn glass capillary tube and positioned with a micromanipulator were injected into a Radiometer Copenhagen BMS3 Mk 2 Blood Micro System (bath temperature regulated at $5^{\circ} \mathrm{C}$ ) connected to a PHM7 1 Mk 2 acid-base analyzer for determination of their oxygen contents. A minimum of five samples was taken during a 1-h period in each of seven specimens. The removal of $\mathrm{O}_{2}$ from the burrow irrigation current was calculated by subtracting the above values from those for incurrent water. The redox profile of undisturbed sediment and of sediment in the same bowl but 
immediately adjacent to burrow excurrent channels was measured with the platinum electrode positioned by a micromanipulator. The oxygen partial pressure in Ctenodiscus crispatus perivisceral fluid was determined for samples removed by puncturing the aboral skin and injected into the Blood Micro System.

\section{RESULTS}

\section{Sediment Organic Content}

Total organic content differed greatly between sediment derived from mud stars and the environment (Fig. 1). Organic material in sediment from animals averaged $28.2 \%$ of total sample weight. Environmental sediment averaged $9.7 \%$ organic content by weight. The range of mean values for organic content by col-

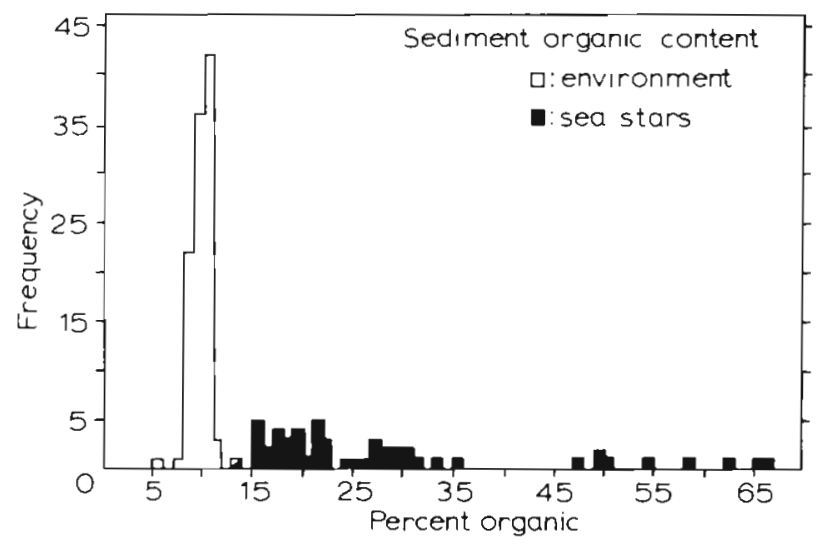

Fig. 1. Individual values for organic content of sediment (percent of dry weight) from all mud star stomachs ( $N=52$ ) and environmental samples $(\mathrm{N}=112)$ collected by various methods described in text

lection date was wider in sediment samples from mud stars $(20.5 \%-43.3 \%)$ than in environmental samples $(8.7 \%-10.5 \%)$. The range of individual values (Fig. 1) was $15.05 \%-66.9 \%$ for sea stars and $5.3 \%-13.0 \%$ for environmental sediment samples. The organic content of samples from the cardiac stomach of mud stars was significantly higher than from environmental samples $(P=0.0042)$

\section{Particle Size Analysis}

Particle size analysis of environmental sediments indicates that the substrate of the study area is fairly uniform and homogenous in structure, both with increasing sediment depth and from site to site (Table 1). The sediment is very fine-grained, and silt and claysized particles predominate, averaging $76.2 \%$ and $15.8 \%$ of the substrate, respectively. Sand-sized particles make up a relatively small proportion of all samples, averaging $8.1 \%$ of total sample weight.

Fecal pellets of marine invertebrates were the most frequently observed particles in the sand-sized fraction. Larger size fractions $(<2 \Phi,>250 \mu \mathrm{m})$ often contained worm and amphipod tubes, nuculid bivalves, portions of macroalgae, terrestrial plant debris and occasionally Foraminifera and large diatoms. Diatom tests were most abundant in the 2-3 $\Phi$ $(250-125 \mu \mathrm{m})$ size fraction. Occasionally this fraction also contained disarticulated echinoderm ossicles and sponge spicules. Organic debris unidentifiable by light microscopy often formed substantial portions of samples in all size classes. Meiofaunal organisms were rarely encountered except for occasional mites and nematodes, which were generally in the 1-2 $\Phi$ $(500-250 \mu n$ ) sediment fraction: This may have been due to our collecting methods since kinorhynchs, mites and nematodes are known to be common (S. Tyler, pers. comm.).

Individual mineral grains larger than $4 \Phi$ units $(62.5 \mu \mathrm{m})$ in size were rare in all samples examined and were essentially absent from size classes $>2 \Phi$ $(<250 \mu \mathrm{m})$, although aggregations of smaller particles, apparently partially decomposed fecal pellets, were occasionally encountered in the 1-2 $\Phi(500-250 \mu \mathrm{m})$

Table 1 Ctenodiscus crispatus. Mean percent occurrence of sand, silt and clay in sea star stomachs, comparable sediment samples and all environmental samples

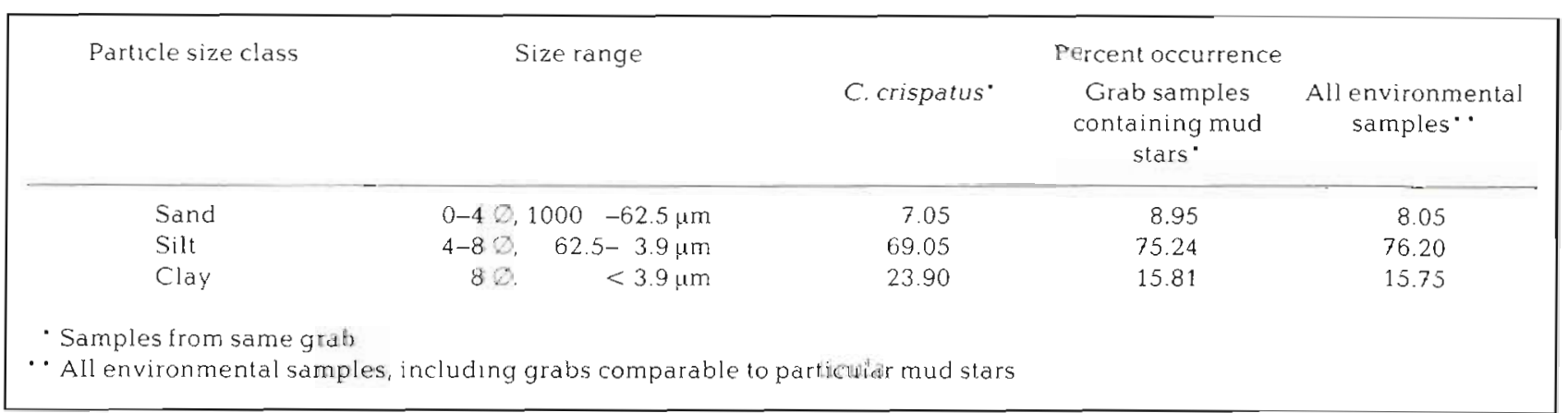



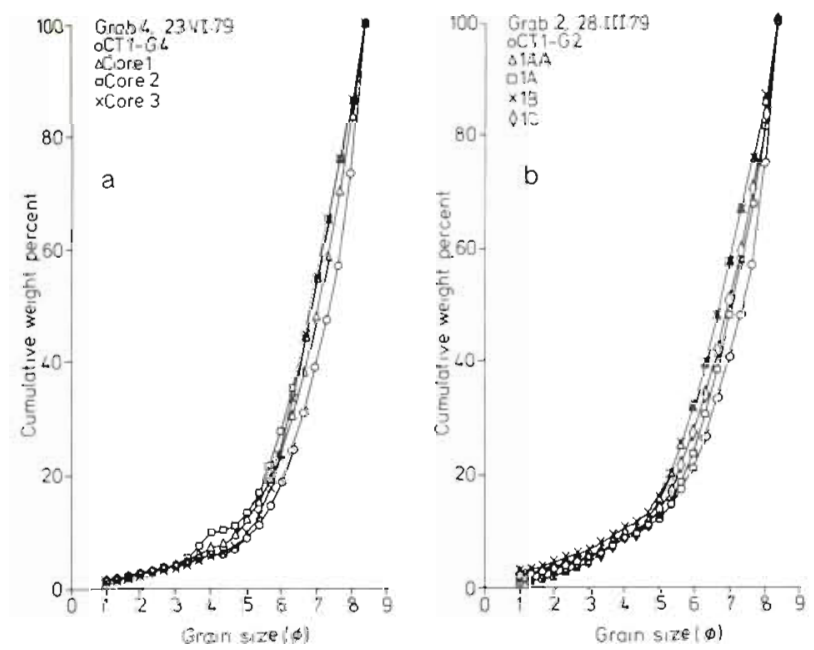

Fig. 2. Particle size distribution plots. (a) Sediment from the stomach of a mud star (CT1-G4), and 3 sediment cores from the same grab sample, 23 June 1978, (b) Sediment from the stomach of a mud star (CT1-G2), and 3 contiguous sediment samples taken at various depths from the same grab. $\mathrm{AA}=$ 0-2 $\mathrm{mm}, \mathrm{A}=2-7 \mathrm{~mm}, \mathrm{~B}=7-12 \mathrm{~mm}, \mathrm{C}=12-22 \mathrm{~mm}$ 28 March 1979

size class. In all cases the largest portion of the sample consisted of mineral and clay particles smaller than $4 \Phi$ units $(62.5 \mu \mathrm{m})$ in size.

Particle distribution of the substrate is uniform with increasing depth throughout the top $2-3 \mathrm{~cm}$ of sediments (Figs 2 and 3), the maximum depth to which subsamples were analyzed, and the depth at which

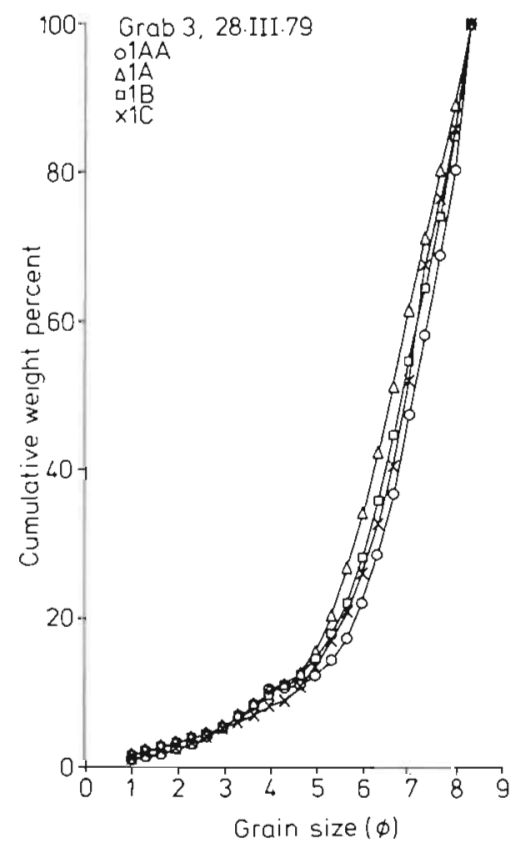

Fig. 3. Particle size distribution plots for 4 contiguous sediment samples taken at various depths from the same grab. AA $=0-2 \mathrm{~mm}, \mathrm{~A}=2-7 \mathrm{~mm}, \mathrm{~B}=7-12 \mathrm{~mm}, \mathrm{C}=12-22 \mathrm{~mm} ; 28$ March 1979
Ctenodiscus crispatus usually makes its burrow. Mixing appears complete to this sediment depth.

\section{Sediment from Animals}

We were successful in obtaining only 5 grab samples that were reasonably undisturbed and also contained undamaged adult mud stars so that direct comparisons could be made between particle size distributions of sediment from sea star stomachs and the environmental sediment in which they were living.

The mean values for the sand, silt, and clay fractions of these 5 environmental samples vary slightly from those of the combined environmental sediment samples for all dates (Table 1). Analysis by arcsine transformation for the equality of two percentages shows the variation is not significant $(P>10)$ in each case. The variation probably stems from the different number of samples in the 2 groups (14 and 52 respectively). The smaller sample size for directly comparable samples introduces a greater error into the mean than does the large sample size for all environmental samples. The 5 samples for direct comparison represent different bottom locations as well as three different seasons of the year: summer, fall, and early spring

Slight differences in the percentages of sand, silt, and clay size classes occur between sea star and sediment samples from the same grab (Fig. 2). The particle size distribution of sediment acquired from animal sources is finer than sediment from the general environment. In either case particles larger than $1 \Phi(500$ $\mu \mathrm{m})$ were generally biologically derived structures such as worm tubes and bivalve shells.

Discriminant factor analysis correctly predicted the classification of a sediment sample as animal or environment $89.5 \%$ of the time when the environment and animal samples from the same grab were analyzed together. Animal samples were correctly classifjed $100 \%$ of the time, and environmental samples were correctly classified $85.7 \%$ of the time.

When asteroid samples were compared individually with sediment samples from the grab in which the mud stars were captured, discriminant analysis correctly predicted group classification in 3 of 5 sample sets. The analysis was unable to separate one sediment core from animal-derived sediment in each of the 2 remaining samples.

Inspection of the particle size distributions of the five matched sample sets, two shown in Fig. 2, indicates that whenever the analysis is able to separate animal from sediment samples, the animal sample is consistently richer in fine size-class particles than is its associated habitat sediment. Each of the cases in which discriminant analysis was unable to distinguish sam- 
ples from each other exhibited animal sediment profiles that were very similar to those in the remaining 3 sample sets. Environmental sediment profiles in indistinguishable cases were more variable than those in distinguishable cases, and in each set at least one of the environmental sediment profiles closely parallels the animal sample.

One sample set allowed the comparison of a mud star with sediment depth horizons from the grab in which it was captured (Fig. 2b). Throughout the majority of the range the mud star exhibits a particle size distribution that is finer than any of the vertical depth horizons in the sediment surrounding it. Discriminant analysis clearly separates the environment from the animal sample in this case (Edwards, 1980).

The largest portion of the animal sediment available for analysis was derived from mud stars collected by trawl on 26 July 1979. The mean values of sand, silt, and clay-sized particies in the stomachs of these animals varied considerably from the corresponding values for specimens from the grab samples. For this reason, sediment data from trawl-collected sea stars were not compared with environmental sediment data. Some sediment fractions likely could have been lost from the sea star during capture by trawling.

Particle species found in sediment obtained from animal stomachs were similar to those found in environmental sediment, although the frequency of unidentifiable organic material relative to identifiable particles was higher in mud stars, probably the effect of digestion. As in environmental sediments, the larger size fractions $\left(<2 \Phi_{1}>250 \mu \mathrm{m}\right)$ consisted primarily of worm and amphipod tubes, terrestrial plant and macro-algal remains, and nuculid bivalve shells and fragments. Shells and fragments of shells seemed slightly less abundant in mud star samples than in the general environment. Diatoms were occasionally important in the $1-2 \Phi(500-250 \mu \mathrm{m})$ size class. Additionally, several mud stars contained one or more small crustaceans or mites in this size range

Fecal pellets, diatoms, and mineral flakes in various degrees of conglomeration (perhaps the remains of fecal pellets) dominated the size classes from 2-4 (250-62.5 unı) Fragmented echinoderm ossicles and sponge spicules were occasionally found in these size classes. The $>4 \Phi(<62.5$ ur $)$ fraction consisted primarily of mineral chips and flakes, and clay particles ranging to $>8 \Phi(<3.9 \mu \mathrm{m})$ in size. There were few or no identifiable organisms or remains in this size fraction.

\section{Morphology and Behavior}

The aboral surface of Ctenodiscus crispatus (Fig $4 \mathrm{a}-\mathrm{c}$ ) is thin and flexible, and is covered with many paxillae. Each paxilla consists of a stout central column crowned with a variable number $(4-10)$ of spinelets. There is no particular pattern of distribution of paxillae with different numbers of spinelets.

Because of the flexible nature of the aboral surface, the profile of the sea star is variable, and reflects the degree to which the stomach is filled with sediment or water Individuals that have recently engorged themselves with mud exhibit a highly rounded profile. The aboral surface of empty specimens may be flat or slightly concave. An anus is lacking. The center of the aboral body wall is particularly extensible, and forms a prominent epiproctal cone (Fig. 4a). The degree of epiproctal cone extension is variable. The epiproctal cone may be inverted, or its height may be several times greater than the height of the marginal plates. In a burrowed mud star, the tip of the epiproctal cone typically is all that is visible, either in a shallow pit or protruding above the sediment surface

The epidermis of the aboral surface contains numerous retractile dermal branchiae, or papulae. Each papula chamber is continuous with the perivisceral cavity through a pore in the integument, allowing circulation for gas exchange. The papulae are capable of great extension. An inflated papula generally stands at least as tall as the suture lines between individual spinelets and the column of an adjacent paxilla (Fig. $4 c)$ and is capable of further extension. Papulae are retracted in response to irritation.

Both the floor of the aboral surface and the papulae are ciliated. Ciliation extends up the paxillar column approximately as far as the suture lines between column and spinelets (Fig. 4c). Beyond this point on the column ciliation rapidly diminishes, and the spinelets and crown of a paxilla are not ciliated.

The general direction of ciliary movement on the aboral surface of the mud star is from the center of the disc and arms to the perimeter, specifically into channels leading between adjacent marginal plates. Currents move around the bases of paxillae and papulae and perhaps up them as well, although it was impossible to determine the latter with certainty. Mucus strings are frequently found on the aboral surface, and in some cases strings and sheets of mucus may be suspended from paxilla crowns.

Pairs of massive marginal plates surround the perimeter of Ctenodiscus crispatus. Each pair consists of a dorsal superomarginal and a ventral inferomarginal plate, both of which have large spines surmounting their upper surfaces.

Between adjacent pairs of superomarginal plates are deep, vertical grooves containing a number of heavily ciliated lamellae. These ciliated channels are termed cribriform organs. Adjacent marginal plates have a series of small spines along their edge that flare out 

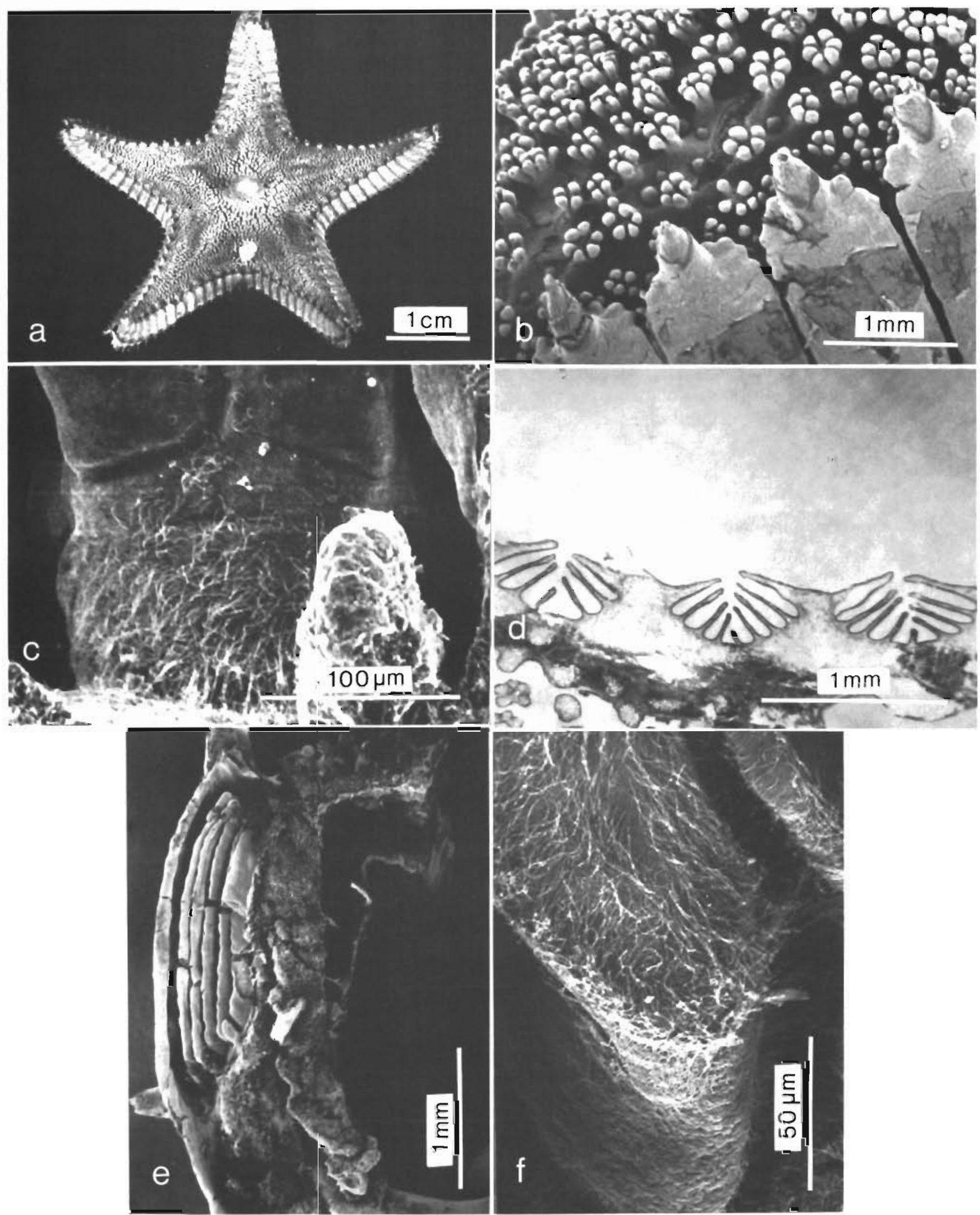

Fig. 4. Ctenodiscus crispatus. (a) A.boral surface and marginal plates, dried specimen, $\mathrm{R}=26 \mathrm{~mm}, \mathrm{r}=12 \mathrm{~mm}$. (b) Aboral arm surface showing paxillae, papulae, and superomarginal plates. (c) Base of a single paxilla showing distribution of cilia on the paxillar column and a partially inflated papula in the right foreground. (d) Cross section of a series of cribriform organs taken from an interradius. (e) Longitudinal section of one half of a cribriform organ showing the orientation of individual lamellae. (f) Upper (aboral) end of a cribriform lamella showing fields of cilia on its surface 
over these grooves to form protective cover lamellae, nearly sealing the cribriform organs laterally. Occasionally, apparent fusion of the epidermis on two cover lamellae occurs, completely bridging the opening between adjacent marginal plates. The lumen of each cribriform organ opens onto the aboral surface of the mud star (Fig. 4b, e). The relatively sparse ciliation of the aboral surface gradually increases in density as the entrance to the cribriform organ is approached.

The number of lamellae in a given cribriform organ is variable and depends on the location of the cribriform organ. Those in the center of an interradius contain the greatest number of lamellae (9-11). Distally, cribriform organs have fewer Iamellae and those at the tips of the arms generally have none.

The surfaces of the cribriform lamellae are covered with microvilli (Fig. 5). The number per cell is variable. TEM sections (Fig. 5b) show that microvillar length varies, and that branching of microvilli occurs.

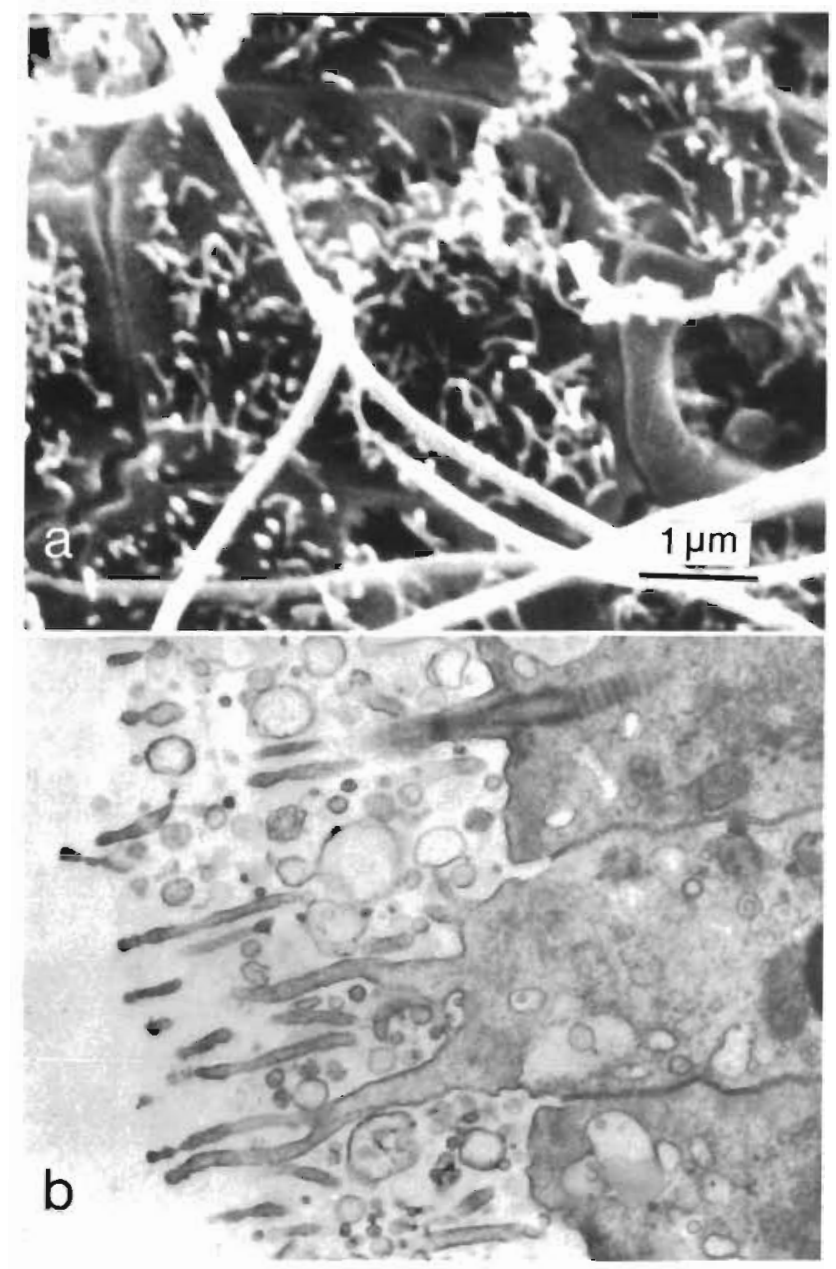

Fig 5. Cienodiscus crispatus. (a) SEM micrograph of the surface of a cribriform lamella showing numerous microvilli on each cell surface; (b) TEM micrograph of the epidermis of a cribriform lamella showing microvilli. 15,000 X
Microvilli are also found on the external surfaces of the mud star although they are usually covered by a thick mucus coat. The number of microvilli per cell on external surfaces is much lower than on the cribriform lamellae

SEM examination indicates that except for cover lamellae, the lamellae of the cribriform organs are closely spaced, generally being separated by a distance of approximately $10 \mu \mathrm{m}$. Cover lamellae are separated from the cribriform lamellae by approximately $125 \mu \mathrm{m}$. Such variation in spacing between cover and cribriform lamellae may be an artifact of SEM sample preparations, since dried mud stars and transverse sections of cribriform organs (Fig. 4d) exhibit even spacing of lamellae perhaps more indicative of the natural state.

In longitudinal section each cribriform organ is a crescent-shaped channel with the lamellae located on the proximal surface (Fig. 4e). Lamellae at the edges of the cribriform organ, immediately beneath the cover lamellae, are longest, approximately $2300 \mu \mathrm{m}$ in length. Lamellae progressively decrease in length toward the center of the cribriform organ, and lamellae in the deepest part of the channel are approximately half as long as those nearest the cover lamellae (Fig. 4d).

Cribriform lamellae do not extend beneath the inferomarginal plates. Instead, a roughly tubular passage reaches from the bases of the superomarginal plates to fascioles on the oral surface of the mud star The walls of this passage are less densely ciliated than the lamellae of the cribriform organ itself.

A rough calculation of the ciliated area of the lamellae of a single full-sized cribriform organ from the center of an interradius gave a value of $11 \mathrm{~mm}^{2}$ per cribriform organ. One commonly finds 12 full-sized cribriform organs, and 16 smaller cribriform organs on each interradius of an average-sized mud $\operatorname{star}(\mathrm{R}=$ $24 \mathrm{~mm}$ ). Assuming that the less than full-sized cribriform organs range from nearly fully developed, toward the base of the arms, to simple channels without lamellae at the arm tips, each was scored as the equivalent of half of a full-sized cribriform organ. Such figures produce a total of 60 full-sized and 80 halfsized cribriform organs on an average-sized mud star with a corresponding total lamellar area of $1100 \mathrm{~mm}^{2}$ individual ${ }^{-1}$.

The passages leading beneath adjacent inferomarginal plates from the cribriform organs empty into fasciolar channels on the oral surface. Like the cribriform organs these channels are not completely closed, but the edges of adjacent plates tend to press closely together more or less isolating the interior of the channel from the surrounding environment. Each fasciole is ciliated, although less heavily than the lamellae of the 
cribriform organ. Microvilli are also much less numerous. The ciliary fields between the two regions are continuous.

A strong, orally-directed current flows throughout the cribriform organ/fasciolar system. Carmine particles deposited on the aboral surface of a healthy mud star are carried to the perimeter of the animal by the aboral ciliation, where they enter the cribriform organs and are transported toward the oral surface. Because the cribriform organs and associated channels are not sealed, particles are frequently ejected from the openings between marginal plates, particularly in the lower half of the system, and especially from the fasciolar channels. Particles transported as far as the ambulacrum are ejected into the region surrounding the podia. No ciliary current was observable in those cribriform organs nearest the arm tips.

Neither the walls nor the floor of the ambulacral groove are ciliated. Particles entering the ambulacrum from fasciolar channels generally exhibit movement, but such movement is random and seems directly linked with water currents created by podial activity. Podia are paired, lack sucking discs, and are pointed as in the case in many other soft-sediment dwelling sea stars. The tip of each podium has a distinct glandular region. Mucus is frequently observed in the ambulacrum and may be produced by the podial tips. Podial surfaces are non-ciliated.

Podia are utilized in burrowing by the mud star. Two mechanisms are apparent, neither of which predominates in mud stars observed in the laboratory. In the first case, the mud star plows down into the substrate while moving forward. The extended podia are used as anchors or levers in the substrate as the mud star progresses. This method of burrowing results in the lead arm being buried first, and the rest of the body progressively follows.

The second method of burrow formation involves sinking vertically into the sediment. The extended podia are used to scoop to one side the sediment lying beneath the body of the mud star, and the animal gradually sinks into the cavity thus excavated, in a manner similar to that reported for the genus Astropecten (Kenk, 1944; Christensen, 1970). The result of either burrowing process generally leaves only the epiproctal cone and occasionally the arm tips visible.

Although Ctenodiscus crispatus is probably capable of moving through the sediment without coming to the surface, as is reported for other sediment-dwelling asteroids, this was not observed in the laboratory. This may have been owing to the relatively small size of the containers used to hold the mud stars.

The peristomial membrane is capable of great expansion, creating a mouth opening at least a centimeter across in adults. The stomach lining is clearly visible through this opening, and on occasion is extended through the mouth frame. The peristomial membrane is not ciliated.

Wide retraction of the peristomial membrane may be involved in a feeding response or a clearing mechanism in which surface particles become trapped in mucus and ingested. On one occasion a mud star being observed for ciliary currents on the oral surface exhibited an intriguing set of behaviors. As carmine particles originating on the aboral surface collected at the bases of the podia they became increasingly embedded in mucus apparently originating from the tube feet. Such particles were progressively concentrated at the podial tips. To accomplish this, adjacent podia would dip into the mucus surrounding their bases, collect some amount of it, and rub it off on the surface of another podium. Continued rubbing of podia concentrated masses of mucus-embedded particles at the tips of the podia. The mucus thus collected was then passed orally to the next podium in sequence. The peristomial membrane was fully expanded at this point, clearly exposing the stomach lining. As the podia adjacent to the mouth received mucus from the more distal podia, they were extended through the mouth frame and into contact with the stomach lining. The effect of this action was to concentrate mucus and embedded carmine particles in the stomach of the mud star.

\section{Uptake of Primary Amines}

The concentration of dissolved primary amines in inshore clayey-silt in the Gulf of Maine averages $4.4 \mu \mathrm{M}(\mathrm{N}=14)$, ranging from 2.6 to $12.8 \mu \mathrm{M}$ (glycine equivalents). Primary amines do not appear to be stratified according to depth, at least in the upper $3 \mathrm{~cm}$

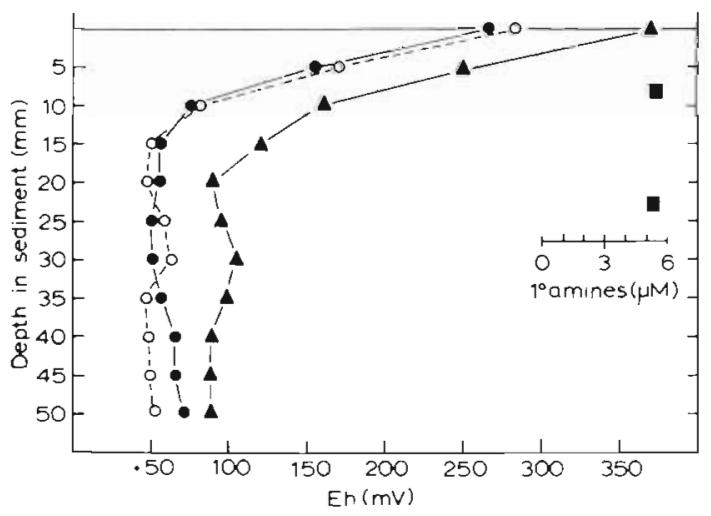

Fig. 6. Redox (Eh) profiles in undisturbed cores taken 24 August 1977. Circles: duplicate cores taken from grab sample 1 Triangles: redox profile in core from grab sample 2. Squares: primary amine concentrations in interstitial water from top $1.5 \mathrm{~cm}$ and next $1.5 \mathrm{~cm}$ horizons of sediment in grab sample 1 . Sediment temperature $=7.2^{\circ} \mathrm{C}$ 
of sediment (Fig 6), in agreement with the thorough mixing of the sediment noted above. Redox profiles of undisturbed cores reveal that the sediment is oxidizing in nature, Eh remaining above $+50 \mathrm{mV}$ in the upper $5 \mathrm{~cm}$, with the greatest change in potential occurring between the sediment surface and $1 \mathrm{~cm}$ depth (Fig. 6). Patches of reduced sediment (indicated by the smell of hydrogen sulfide) were also encountered in grab samples, and specimens of Ctenodiscus crispatus were sometimes present in these samples. The concentration of a single sample of primary amines from such sediment was $6.6 \mu \mathrm{M}$.

Experiments in which adult specimens (1-2 g dry weight) of Ctenodiscus crispatus were exposed to interstitial water expressed from sediments yielded equivocal results concerning the uptake of primary amines. Because of the ease with which the papulae of these specimens are damaged during removal of surface mucus and sediment, it was difficult to ensure that the experimental animals were intact. Microscopic examination of the papulae often revealed that they had been ruptured, thus allowing perivisceral fluid to

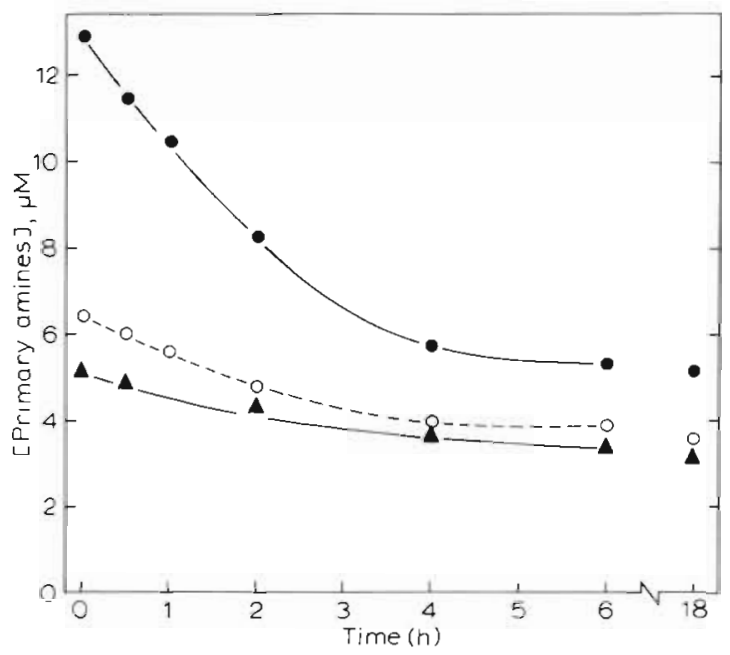

Fig. 7. Ctenodiscus crispatus. Depletion of naturally occurring primary amines from initial concentratıons of $5.1(\mathbf{4}), 6.6(0)$, and $12.8(\bullet) \mu \mathrm{M}$, by juvenile mud stars of 55,55 , and $53 \mathrm{mg}$ wet weight, respectively

leak into the incubation medium and accounting for the apparently net leakage of primary amines.

Repetition of uptake experiments using less easily damaged juvenile specimens (average $15 \mathrm{mg}$ dry weight) produced clear evidence of a net uptake of natural primary amines from initial concentrations of $5.1,6.6$, and $12.8 \mu \mathrm{M}$ (Fig. 7) in interstitial water The residual concentration of primary amines was directly related to the initial concentration, and the implications of this will be discussed below

Despite the occurrence of a net uptake of total prim- ary amines, there was also a measurable release of these substances into the medium. When juveniles were exposed only to ${ }^{14} \mathrm{C}$-glycine (initial concentration $=6.6 \mu \mathrm{M})$ in artificial seawater and the disappearance of glycine monitored simultaneously by fluorometry and liquid scintillation counting, the curves diverged after about $1.5 \mathrm{~h}$ (Fig. 8 ). Total radioactivity in

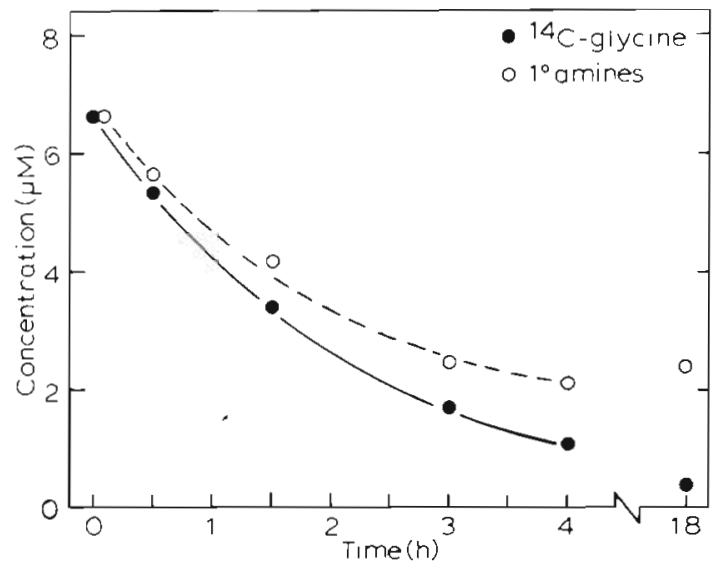

Fig. 8. Ctenodiscus crispatus. Depletion of ${ }^{14} \mathrm{C}$-glycine from an initial concentration of $6.6 \mu \mathrm{M}$, measured simultaneously by liquid scintillation $(\bullet)$ and fluorometric $(0)$ techniques. Animal wet weight $=65 \mathrm{mg}$. For comparison, see depletion of naturally occurring primary amınes from the same inutial concentration (Fig. 7), and text for discussion

acidified (to drive off ${ }^{14} \mathrm{CO}_{2}$ ) seawater samples declined exponentially, achieving a final level equivalent to $0.3 \mu \mathrm{M}$ glycine. Total fluorescamine-positive materials reached a plateau at about $2 \mu \mathrm{M}$ after $4 \mathrm{~h}$, increasing to $2.3 \mu \mathrm{M}$ by $18 \mathrm{~h}$. Following Wright and Stephens (1978) and Stephens et al. (1978), we interpret these results as indicating the release of unidentified primary amines into the medium simultaneous with the accumulation of labelled glycine by the mud stars.

The entry of glycine into Ctenodiscus crispatus tissues proceeds by saturable and non-saturable pathways (Fig. 9). Wright and Stephens (1978) have explained the non-saturable component as being due to the rapid labelling of a large extracellular (inulin) space in mussel gills, and Ahearn and Townsley (1975) likewise convincingly invoke a large inulin space to account for non-saturable entry of amino acids into the holothurian Chiridota rigida. Although extracellular space has not been measured in the present experiments, such an explanation is likely applicable to $C$. crispatus as well. The saturable, carrier-mediated entry of glycine therefore has been quantified by calculating the constant for non-saturable entry using regression analysis of the linear portion of the uptake curve (rates at 18.8 to $101.3 \mu \mathrm{M}$ ) and correcting the data according to the method of Muscatine and D Elia 


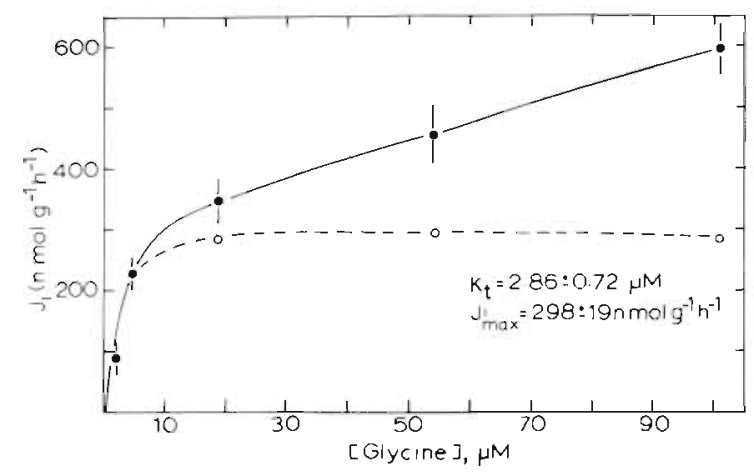

Fig. 9. Ctenodıscus crispatus. Kinetıcs of ${ }^{14} \mathrm{C}$-glycine uptake by juvenile specimens. Closed circles: uncorrected data; cach point represents mean, bars \pm 1 standard error, of determinations on 3 individuals. Open circles: data corrected for unsaturable entry as described in text

(1978). The corrected data (Fig. 9) have been used to calculate the kinetic parameters $J_{\text {mad }}^{\prime}$ (maximum rate of saturable glycine influx) and $K_{t}$ (glycine concentration at which $J_{1}=0.5 J_{m \mathrm{~d} x}^{\prime}$ ) using the statistical program of Wilkinson (1961) for enzyme kinetics. The values obtained are $J_{\max }^{i}=298$ ( \pm 19 S.E.) $\mathrm{n}$ moles $\mathrm{g}$ dry weight ${ }^{-1} \mathrm{~h}^{-1}$ and $K_{l}=2.86$ ( $\pm 0.72 \mathrm{~S}$. E.) $\mu \mathrm{M}$, the latter value being about an order of magnitude lower than those reported in the literature for most other infaunal marine invertebrates. The corrected $K$, for asparate is $3.14 \pm 0.33 \mu \mathrm{M}$ and $J_{\operatorname{ma\lambda }}^{\prime}$ is $28.42 \pm 0.54 \mathrm{n} \mathrm{moles}^{-1}$ $\mathrm{h}^{-1}$. These values are unchanged by the addition of $100 \mu \mathrm{M}$ glycine to the incubation medium, being 4.06 $\pm 1.01 \mu \mathrm{M}$ and $30.44 \pm 1.58 \mathrm{n}$ moles $\mathrm{g}^{-1} \mathrm{~h}^{-1}$, respectively, indicating separate carrier systems for these amino acids.

\section{Burrow Irrigation and Oxygen Uptake}

Ctenodiscus crispatus clearly irrigates its burrow with oxygenated water. A given burrowed specimen may show from 1 to 5 excurrent channels (Fig. 10), so irrigation is not necessarily symmetrical. Redox profiles of sediment immediately adjacent to distinct excurrent channels at the tips of arms are more strongly oxidized than are undisturbed sediments in the same bowl and sediments adjacent to arm tips without excurrent channels (Fig. 11). The burrows had been established at least $5 \mathrm{~d}$ prior to the redox mea-

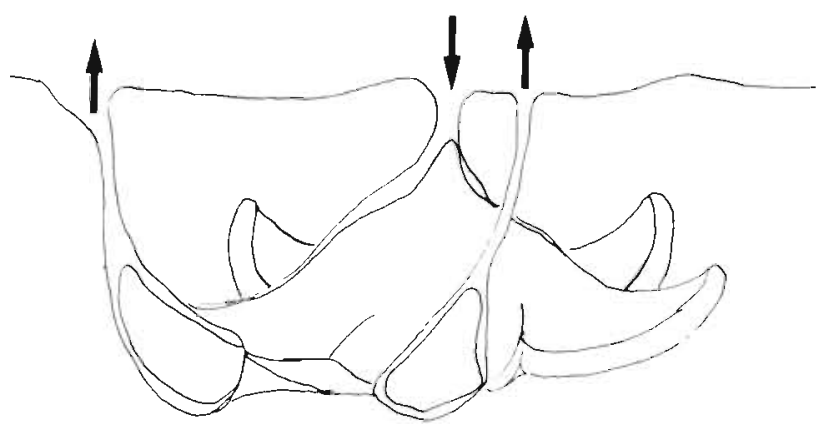

Fig. 10: Ctenodiscus crispatus. Schematic drawing of adult specimen $(\mathrm{R}=24 \mathrm{~mm}$ ) in burrow. Arrows show incurrent and excurrent flows of irrigation current

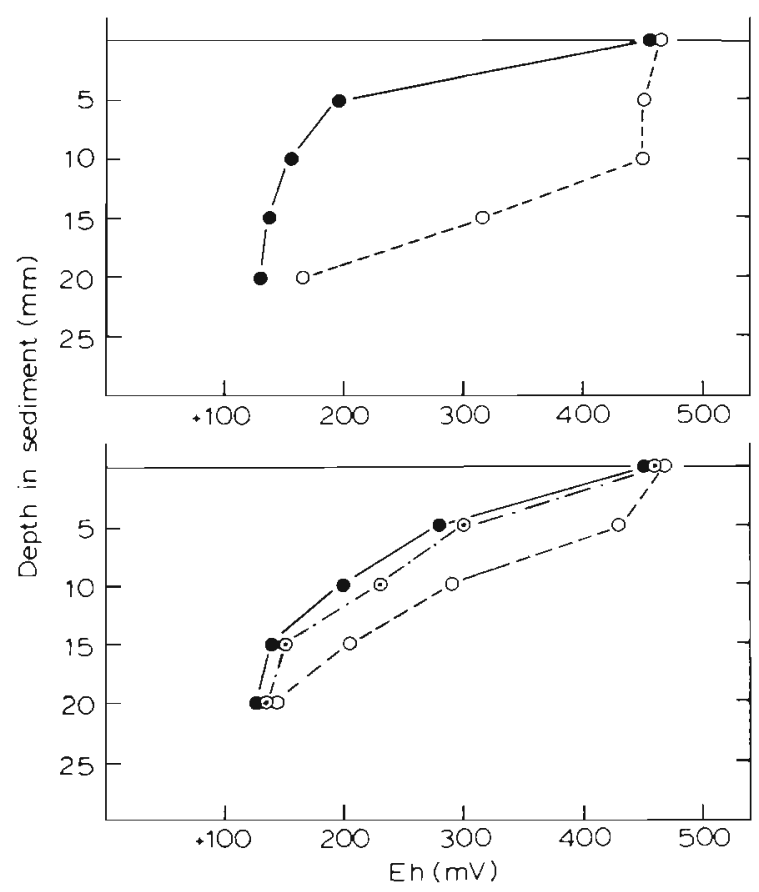

Fig. 11 Ctenodiscus crispatus. Redox (Eh) profiles in sediment inhabited by 2 adult specimens (top and bottom, respectively) in the laboratory. Closed circles: sediment several $\mathrm{cm}$ away from burrow. Open circles: sediment adjacent to arms having distinct excurrent channels from the burrow. Dotted circles: sediment adjacent to arm lacking excurrent channel

surements, so the proviles obtained represented the steady-state condition.

At an incurrent $P_{\mathrm{O}_{2}}$ of $159 \mathrm{~mm} \mathrm{Hg}$ (oxygen content $7.22 \mathrm{ml} \mathrm{l}^{-1}$ at $5^{\circ} \mathrm{C}$ ), Ctenodiscus crispatus removes

Table 2. Ctenodiscus crispatus. Parameters of water transport and oxygen uptake in a $1.5 \mathrm{~g}\left(\mathrm{dry}\right.$ weight) specimen at $5^{\circ} \mathrm{C}$. See text for definition and discussion of each quantity

\begin{tabular}{|c|c|c|c|c|c|c|c|}
\hline $\begin{array}{c}P i_{0_{2}} \\
(\mathrm{~mm} \mathrm{Hg})\end{array}$ & $\begin{array}{c}P e_{\mathrm{O}_{2}} \\
(\mathrm{~mm} \mathrm{Hg})\end{array}$ & $\% E_{x t r_{w}}$ & $\begin{array}{c}P_{p f_{02}} \\
(\mathrm{~mm} \mathrm{Hg})\end{array}$ & $\% E w_{0_{2}}$ & 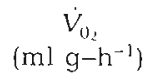 & $\begin{array}{c}\dot{V}_{w^{\prime}} \\
\left(\mathrm{ml} \mathrm{g}^{-1}\right)\end{array}$ & $\begin{array}{l}\dot{V}_{w} / \dot{V}_{0_{2}} \\
\left(1 \mathrm{ml}^{-1}\right)\end{array}$ \\
\hline 159 & 146 & 8.2 & 135 & 54 & 0.020 & 33.8 & 1.69 \\
\hline
\end{tabular}


7.34 ( \pm 0.94, S.D.) $\%$ of the oxygen from the irrigation current. Because of the large volume of water flow (Table 2) and the large biomass of sea star tissue in contact with it, any microbial or abiological chemical contributions to the $7 \%$ oxygen utilization are probably negligible. The directly determined $\dot{V}_{\mathrm{O} 2}$, oxygen utilization ( $\%$ Extr ${ }_{w}$ ), and perivisceral fluid $P_{\mathrm{O} 2}$ in a $1.5 \mathrm{~g}$ individual have been used to calculate the respiratory parameters in Table 2 . The rate of water flow, $\dot{V}_{w}$, was calculated using the fundamental relationship $\left(\dot{V}_{w} / \dot{V}_{\mathrm{O} 2}\right) \quad \%$ Extr $_{w} \cdot C_{\mathrm{jO} 2}=1.0$, (Dejours, 1975) where $C_{102}$ is the oxygen content of the incurrent water. The effectiveness of $\mathrm{O}_{2}$ removal from the irrigation current, $\% E_{\mathrm{wO}_{2}}$, or the ratio of actual to maximum possible oxygen removal (Johansen and Petersen, 1971), was calculated as $\left(\mathrm{Pi}_{\mathrm{O} 2}-\mathrm{P}_{\mathrm{eO} 2} / \mathrm{Pi}_{\mathrm{O} 2}-\mathrm{P}_{\mathrm{pro} 2}\right) \times 100$, where $P_{\mathrm{jO} 2}$ and $P_{\mathrm{eO} 2}$ are the oxygen partial pressures in the incurrent and excurrent water, and $P_{p / O 2}$ is that in the perivisceral fluid. $C$. crispatus does not have a respiratory pigment, and the capacitance $(\beta)$ of perivisceral fluid is assumed to be the same as that of seawater.

\section{DISCUSSION}

An infaunal existence in easily disturbed sediments of very fine particle size accounts for a number of structural and physiological adaptations in Ctenodiscus crispatus which are not seen in most asteroids. The habitat and the morphological features are similar to those in the deep-sea Porcellanasteridae, and the results of our studies of the functional morphology and physiology of C. crispatus may be applicable to these animals as well.

\section{Deposit Feeding}

The results suggest that Ctenodiscus crispatus is nonselective and feeds on bulk sediment. The mud star occurs in an environment which renders unnecessary an energy expenditure for particle sorting. Several facts support this idea. First, the organic content of the sediments encountered is relatively high, averaging $9.7 \%$ of the substrate by weight. Very few values for sediment organic content reported in the literature, which range from $0.1 \%$ in the deep sea (Sanders et al., 1965) to $17.4 \%$ in the intertidal and shallow subtidal sediments (Johnson, 1974), are higher. Second, the range of mean sediment organic content is very narrow, and shows little or no seasonal variation. Thus the sediments of the study area represent a rich and constant food resource for deposit feeding organisms. Finally, the particle size distribution of sediments in the study area is nearly uniform, and very fine. The constancy and fine nature of the particle distribution implies a large surface area for a given volume of sediment throughout the study area, which provides a large substrate for bacterial growth (cf. Hargrave, 1972; Dale, 1974). This fact, and the presumed allochthonous organic inputs from the Damariscotta River estuary, are probably responsible for the unusually high organic content of these sediments.

The terrestrial origin of much of the organic detritus in our samples, however, suggests that it is refractory and not directly available to deposit feeders. Recent studies have shown that the bacteria associated with particulate organic matter are probably the primary nutritional source for detritivores (see Newell, 1979, for many references and review). Deposit feeders from more heterogeneous sediments select food particles by size (Rhoads and Young, 1971; Whitlatch, 1974; Fenchel et al., 1975; Hauksson, 1979). Other sediment properties, such as specific gravity and surface texture, can be used in sorting (Clifton and Thompson, 1978; Self and Jumars, 1978). In all of these cases a large bacterial population on the particles may make them attractive to deposit feeders.

In contrast to such selectivity, mud star stomach contents and environmental sediment show marked similarity in particle size distribution (Fig. 2). The only apparent difference between the two is that the mud star generally shows a particle distribution that is slightly enriched in the finest particle sizes as compared to the environment. As outlined below, this discrepancy is probably related to burrow irrigation and efforts by the mud star to keep epidermal surfaces clear of fouling particles.

On average, sediment obtained from the stomachs of sea stars contains three times more organic material $(28.1 \%$ vs $9.7 \%)$ than the environmental sediment by weight, implying some means of organic enrichment. Additionally, the range of mean values observed is very wide. This degree of variation in the organic content of sediment in the animal cannot be accounted for by variations in the organic content of environmental sediments in the study area.

Organic enrichment of the stomach contents of mud stars could occur in several ways. At least some of the variation observed is probably owing to the secretion of digestive juices into the stomach during digestion. Since it proved impossible to induce animals to feed in the laboratory, the stage of digestion at which samples were taken could not be controlled.

Secondly, some organic contamination may have resulted from the forced extrusion of sediment from the mouth of the mud star, which, however gently done, may damage internal tissues and cause release of body fluids into the stomach contents. 
A third possibility is that mucus enrichment of the stomach contents occurs, and we in fact have observed the mud star to ingest this material, although we do not concur with Gislén's (1924) assessment that Ctenodiscus crispatus is a ciliary-mucoid feeder, as discussed below. Mucus likely keeps the respiratory surfaces clear of fouling particles, an important function in an infaunal animal respiring through exposed epidermal structures.

Why should Ctenodiscus crispatus be a nonselective deposit feeder when it would appear advantageous to ingest selectively the smallest particles present (Taghon et al., 1978), since these should have the highest organic content (see Newell, 1979 for review) and represent the best food resource? Two possibilities are sugested. First, the study area represents an unusually rich and uniform food source for deposit feeding animals. Second, the particle distribution of the sediment is homogeneous and extremely fine. The combination of these factors produces a situation in which no particle selectivity is required to maximize organic input.

\section{Cribriform Organ Function}

Since Ctenodiscus crispatus is not a selective deposit feeder, what is the function of the cribriform organs, as it would appear that their closely opposed, heavily ciliated lamellae (Fig. 4, d, e, f) are ideal for particle sorting? Past authors have attributed several functions to the cribriform organs. Sladen (1883) described porcellanasterid cribriform organs as 'percolators', apparently in reference to the water currents that pass through them, and was of the opinion that they were respiratory in nature. Gislen (1924), observing C. crispatus, concurred with Sladen about a probable respiratory function, but also noted that small particles were carried through the cribriform organs to subsequent entrapment in mucus and eventual ingestion, suggesting a role in ciliary-mucoid feeding. Lieberkind (1935) noted the presence of amoebocytes in the ciliated epithelium of the lamellae in C. crispatus and postulated that one of their functions was excretion. Madsen (1961a) stated that both respiration and feeding are accomplished with the cribriform organs but did not suggest an excretory function.

None of the above hypotheses was verified by observing living specimens burrowed in mud. When Ctenodiscus crispatus is maintained in the laboratory, it establishes a temporary burrow (which it occupies from several days up to several weeks) and produces strong currents through the burrow, but the wholesale transport of surface material into the burrow is not seen. Carmine particles pipetted directly into the incurrent opening are carried into the burrow, but those placed on the surface of the immediately adjacent sediment are not. (In nature, however, the intake of surface particles resuspended by bottom currents or bioturbation could occur.)

The presence of amphipod and polychaete tube fragments, bivalve shells, and other large particles in the sediment-filled stomachs of many specimens (see 'Results'; also, Sokolova, 1958, and Carey, 1972) argues against Ctenodiscus crispatus being purely a ciliary-mucoid feeder and suggests that the animal ingests sediment in bulk. Although the mud star does indeed ingest mucus-imbedded particles (as originally suggested by Gislén), the principal role of the mucus is to maintain an epidermis unencumbered by such materials, and its ingestion is largely a means of recycling a copious extracellular secretion which is energetically expensive to produce (see Calow, 1977 , pp. 23-27). Because mucus production and consumption is probably variable over time, this mechanism could partly account for the increased variability and richness of the stomach organic content as compared to the surrounding environment, as well as explaining the observations of Gislén.

The slight enrichment of the stomach contents with fine particles (Fig. 2, Table 1), which likely have a higher organic content than larger particles (e.g. Newell, 1979, p. 355 et seq.), probably reflects the fact that the smaller particles are more likely to be separated from the sediment by ciliary currents, passed through the cribriform organs, and subsequently trapped in mucus and ingested. Such a mechanism of particle 'selectivity' is discussed by Self and Jumars (1978).

When Ctenodiscus crispatus irrigates its burrow, a strong excurrent flow occurs through channels extending from the arm tips (Fig. 10), despite the absence of ciliary tracts oriented in this direction (see 'Results'; also, Gislén, 1924). Such a large flow, which is directed through the oral fascioles and along the ambulacra, is actually created in the cribriform organs (specifically, by the heavy ciliation on the cribriform lamellae), which act as 'turbines' and create sufficient force to drive the water through the sparsely ciliated, lamellalacking channels beneath the inferomarginal plates, into the sparsely ciliated fascioles and non-ciliated ambulacral grooves, and out of the burrow via the hydraulically-excavated excurrent channels.

\section{Burrow Irrigation and Oxygen Uptake}

The irrigation of a burrow by the mud star provides an opportunity to examine respiratory parameters not feasible in other asteroids. The extraction of oxygen 
from this current averages about $7-8 \%$, the same as in most benthic filter-feeding invertebrates employing cilia-driven currents and lacking respiratory pigments (Jorgensen, 1975; Mangum and Burnett, 1975; Bayne et al., 1976; Mangum, 1977). This value is lower than the $18 \%$ seen in Pteraster tesselatus (Johansen and Petersen, 1971), which uses muscle-driven, tidal ventilation of its primary respiratory surface in its nidamental chamber The convection requirement $\left(\dot{V}_{w} / \dot{V}_{\mathrm{O} 2}\right)$, or liters of water pumped per milliliter of $\mathrm{O}_{2}$ removed from the current, is 1.69 in Ctenodiscus crispatus. This value is only slightly higher than that in a variety of animals having respiratory pigments and employing muscle-driven, truly respiratory currents (Mangum, 1977). Interestingly, it is similar to the value of about 1.6 (calculated from the data in Johansen and Petersen, 1971) in Pteraster tesselatus, although a direct comparison is difficult because oxygen entry is not restricted to the actively-ventilated nidamental chamber in $P$. tesselatus. The convection requirement in C. crispatus is lower than that in filter-feeding bivalves (ca 3-20: Jørgensen, 1966, 1975; Bayne et al., 1976), in which the current is more closely adjusted to feeding, rather than to respiratory, requirements.

It is generally accepted that the low percentage of $\mathrm{O}_{2}$ extraction by bivalves reflects the feeding nature of the irrigation current, but this hypothesis was framed mindful of the low availability of particulate food and in the absence of relevant data on gas exchange parameters. More pertinent than the percent of $\mathrm{O}_{2}$ removed is the actual effectiveness ( $\left.\% E_{w 02}\right)$ of its removal, the ratio of actual uptake to the maximum possible, given the diffusion gradient that exists. The value in Ctenodiscus crispatus is $54 \%$, a rather high value that is identical to that in Pteraster tesselatus, and may be related to the effective convection of the external and internal (see Shick, 1976) media in these, relative to other, asteroids. The maintenance of a high $P_{\mathrm{O} 2}$ in a large volume of perivisceral fluid in C. crispatus (Table 2) may be important as an oxygen store during temporary burial in unstable sediments and during excursions deeper into the sediment.

These relationships indirectly argue for the primacy of a respiratory, as opposed to a feeding, function of the ciliary currents through Ctenodiscus crispatus burrows. The adoption of a cilia-driven respiratory current (from which oxygen extraction is low) by this species and by other goniopectinid and porcellanasterid sea stars likely relates both to the hydrodynamic and mechanical limitations imposed by the basic asteroid body plan, and to the fragile nature of the burrow in silty sediments. Rhoads and Young (1970) have noted that mobile deposit feeders disturb soft sediments and interfere with the activities of suspension feeders, and Levinton (1977) has extended this concept to generalize that active and sedentary deposit feeders are likewise largely incompatible; both of these studies implicate the difficulty in maintaining unimpaired gas exchange surfaces in fine sediments as a major factor in determining soft-bottom community structure. C. crispatus is a potentially mobile deposit feeder having a respiratory surface that is highly susceptible to clogging. The mud star has adapted to life in easily disturbed sediments by limiting its mobility and establishing temporary burrows, using the extensible epiproctal cone to maintain a connection with the water column. The burrow itself is irrigated by ciliary currents, which, based on laboratory observations, provide a continuous respiratory flow with a minimum of disturbance of the flocculent sediment.

\section{Uptake of Primary Amines and Glycine}

The rather low concentration (2.6-12.8 $\mu \mathrm{M}$ ) of primary amines in interstitial water reported in this study is in good agreement with the only other data for amino acid concentrations in oxidized sediments in the Gulf of Maine (Henrichs and Farrington, 1979) and in oxidized sediments elsewhere (Degens, 1970; North, 1975). This concentration is an order of magnitude lower than that in reduced sediments (Degens, 1970). Based on studies of the uptake and release of these compounds from the very high concentrations prevailing in intertidal, reduced sediments by invertebrate infauna (Stephens, 1975; Crowe et al., 1977; Stephens et al., 1978; Costopulos et al., 1979), the likelihood of their net uptake from the very low concentrations reported here would at first appear to be slight. However, the transport systems in Ctenodiscus crispatus are adapted for accumulating primary amines from the low ambient concentrations in the habitat.

A net uptake of naturally occurring primary amines by Ctenodiscus crispatus has been demonstrated (Fig. 7). This is related to the very high affinity of the transport systems involved, the $K_{t}$ for glycine and aspartate being approximately $3 \mu \mathrm{M}$. These values are thus in the same range as their concentrations in interstitial water. Also, the glycine transport system has a very high capacity $\left(J_{\max }^{\prime}=298 \mathrm{n}\right.$ moles $\left.\mathrm{g}^{-1} \mathrm{~h}^{-1}\right)$.

After juvenile mud stars were exposed to solutions of natural primary amines, the residual concentration in the medium was directly related to the initial concentration provided (Fig. 7). This result may be explained in part by the presence in interstitial water of fluorescamine-positive substances for which there is no transport system, or one of very low activity. Likely candidates are the acidic amino acids. Henrichs and Farrington (1979) report that glutamic acid and its isomer, $\beta$-aminoglutaric acid, and aspartic acid, predominate 
among the amino acids in Gulf of Maine sediments. (Glycine is the next most concentrated amino acid). Our results indicate that although the affinity of the aspartate transport system in Ctenodiscus crispatus is high, its activity is low $\left(J_{\max }^{i}=28 \mathrm{n}\right.$ moles $\left.\mathrm{g}^{-1} \mathrm{~h}^{-1}\right)$, an order of magnitude lower than that of the glycine carrier A low activity of acidic amino acid transport systems has precedent in another echinoderm, the sand dollar Dendraster excentricus (Stephens et al., 1978), and in some annelids (Stephens, 1975) and pogonophorans (Southward and Southward, 1980). There is also a release into the medium of primary amines from $C$. crispatus, as seen in the experiments in which glycine concentration was measured both radiochemically and fluorometrically (Fig. 8).

Despite the low rate of uptake of some components of the interstitial medium and the release of some primary amines into it, the fact of a net uptake of total primary amines nevertheless remains. Assuming that $1 \mathrm{mg}$ of mixed amino acids requires $1 \mathrm{ml}$ of $\mathrm{O}_{2}$ for complete oxidation, the initial rates of uptake from the concentrations shown in Fig. 7 could support 16.5 . 26.5 , and $86.5 \%$, respectively, of the known oxygen consumption rate $\left(200 \mu \mathrm{l} \mathrm{g}^{-1} \mathrm{~h}^{-1}\right.$ at $\left.8^{\circ} \mathrm{C}\right)$ of a $15-\mathrm{mg}$ juvenile, so that dissolved primary amines at natural concentrations make a quantitatively significant contribution to the mud star's diet, although we do not assume that all of the accumulated amino acids necessarily enter oxidative pathways (see Shick, 1975)

Because we do not know the rate at which Ctenodiscus crispatus ingests sediment or what the animal removes from it, the relative importance of dissolved, as opposed to particulate, food sources is unknown. Further, although steady-state concentrations of primary amines in interstitial water in the habitat range from 3-13 $\mu \mathrm{M}$, the seastar irrigates its burrow with seawater from the overlying water column, which likely has a lower content of these substances. Conversely, irrigation of the burrow with oxygenated water may stimulate microbial production in adjacent sediments (Stephens, 1975), which although oxidized, are nevertheless probably anoxic (Revsbech et al., 1980). The resultant final concentration of amino acids at the sea star's skin surface is difficult to predict, thus complicating a quantification of the importance of dissolved exogenous amino acids in its diet.

Using direct and indirect lines of evidence, Sepers (1977) and Siebers (1979) have argued that dissolved organic compounds are quantitatively unimportant in the nutrition of epifaunal and pelagic marine invertebrates. Briefly, they contend that marine bacteria, by virtue of their very low $K_{1}$ values (high affinities) for dissolved organic substances, outcompete invertebrates for these compounds and keep the concentration of dissolved organic matter in seawater low. A large body of evidence indicates that the $K_{l}$ values for various amino acid transport systems are in the same range as the amino acid concentrations normally encountered by the carriers. Thus, the rather high $K_{t} s$ in infaunal invertebrates (reviewed by Jorgensen, 1976 and Stewart, 1979) are interpretable in the light of the high substrate concentrations normally found in their habitat in intertidal, reduced sediments. A seeming inconsistency to the above generalization, that reported $K_{l}$ values in epifaunal and planktonic invertebrates are about an order of magnitude higher than amino acid concentrations in the water column, has only recently been resolved. Wright and Stephens (1978) have shown that the high $K_{t}$ values seen in excised bivalve gill preparations are artifacts due to the presence of unstirred layers at the transport surface. When amino acid uptake is measured in intact, actively-ventilating mussels, in which unstirred layers are eliminated at the gill surface, $K$, values on the order of $1-2 \mu \mathrm{M}$ obtain.

The elimination of unstirred layers at the transporting epithelium likely occurs in Ctenodiscus crispatus as well and probably accounts for the low $K_{t}$ values we observe in this species. Specifically, the lamellae within the cribriform organs are heavily ciliated (Fig. 4f), and moreover, are arranged such that the dimensions of the interlamellar spaces (Fig. $4 \mathrm{~d}$ and e) are within the range consistent with the elimination of unstirred layers by ciliary activity (Winne, 1973; Wright and Stephens, 1978; Wright, 1979). Importantly, the cilia arise from closely opposed surfaces which are richly supplied with microvilli (Fig. 5), the latter being characteristic of transporting epithelia. Further evidence that the cribriform lamellae may be the major sites of amino acid uptake is that microvilli are very sparse in areas such as the channels beneath the inferomarginal plates, fascioles, ambulacrum, and peristomial membrane, all of which surfaces also either lack cilia or are sparsely ciliated and which therefore will have unstirred layers associated with them. Although the cribriform lamellae are restricted to the grooves beneath the superomarginal ossicles (Fig. 4e), they nevertheless present a large surface area for transport: the lamellar surface in an average-sized adult mud star $(1.5 \mathrm{~g}$ dry weight; $R=24 \mathrm{~mm})$ is approximately $11 \mathrm{~cm}^{2}$

Following Ferguson $(1967,1970,1980)$, Pearse and Pearse (1973), Ahearn and Townsley (1975), and Stephens et al. (1978), we realize that only limited exchange of nutrients between the epidermis and internal tissues occurs in echinoderms, so that dissolved organic matter in seawater may be of special importance in the nutrition of superficial tissues. Related to this is the fact that microvilli are common elements of the surface structure of echinoderms - a 
recent electron microscopy study of the echinoderm cuticle by Holland and Nealson (1978) has demonstrated microvilli on the epidermal surfaces of all five extant classes in the phylum. In Ctenodiscus crispatus, much of the energy required for the substantial ciliary activity in the cribriform lamellae that create the burrow irrigation current (and which are especially rich in microvilli) may therefore be derived directly from solution in seawater.

\section{Mode of Life of Ctenodiscus crispatus and the Deep- Sea Porcellanasteridae}

Ctenodiscus crispatus probably spends the majority of its time in temporary burrows in the uppermost layers of the sediment. A connection with the overlying water column is maintained by the extensible epiproctal cone. Respiratory water is pumped across the aboral surface, through the cribriform organs and fascioles of the interradial areas, and into the ambulacral grooves. Excurrent channels are hydraulically excavated from the arm tips to the sediment surface. Most or all of the motive force of the respiratory current is supplied by the ciliation of the cribriform lamellae. Additionally, as outlined above, the respiratory current may supply a significant amount of nutrition to the mud star in the form of DOM. Such uptake is probably especially important to epidermal cell layers, particularly those of the cribriform lamellae. The mucus abundantly produced by the mud star likely serves to keep the epithelium free of fouling particles incidentally drawn into the burrow, rather than having a feeding function.

Because feeding is not ciliary-mucoid in nature, filling the stomach is probably accomplished by simply retracting the peristomial membrane and shoveling substrate into the mouth with the adjacent podia. This could easily be accomplished during burrowing, and would actually reduce the amount of sediment that must be removed from beneath the asteroid. Digestion of the organic content of the sediment, including occasional macrofauna, probably takes place while the mud star resides in the burrow.

Upon completion of digestion the peristomial membrane is opened widely and indigestible material extruded from the stomach, a behavior we frequently observed in freshly-collected specimens. Probably the mud star then moves a short distance before refilling the stomach with sediment. An advantage to surfacing before moving is the ability of maximize intake of the uppermost sediment layers. Although surface sediment does not always contain the smallest particles, primarily owing to sediment reworking and fecal pellet formation by deposit feeders (Rhoads and Young, 1970), the organic content of the flocculent surface layer is usually high, and may be greater than that of the sediment layers below it (Johnson, 1974). This is probably explained by the rapid colonization of fecal material by bacteria (e.g. Longbottom, 1970). Although the sediment at our study site appears extremely well mixed, this condition probably does not obtain in deep-sea sediments which show more stratification owing to smaller populations of invertebrate macrofauna.

Deep-sea asteroids of the family Porcellanasteridae have long been recognized as 'mud swallowers', although Madsen (1961a, p. 50) explicitly states that they 'most certainly do not leave their burrows for feeding. And since they can hardly be considered just swallowing the bottom material below them (which would be of small value as food), ... they are able to secure from above the surface material comparatively rich in organic matter'. This would be accomplished 'by means of water currents created by the cribriform organs, to draw down the surface material ... in order that it may be caught in the mucus secretion and then led to the mouth by the podia' (Madsen, 1961b, p. 181). This is despite his recognition (1961a, p. 50) that porcellanasterid stomachs also contain large items such as pieces of worm tubes, a whole sea urchin, fecal pellets, and terrestrial plan debris, and his related conclusion that these sea stars also act as scavengers and facultative predators. His conclusion of ciliary-mucold feeding is drawn heavily from Gislén's (1924) description of the biology of Ctenodiscus crispatus.

Conversely, Sokolova (1958), in a study of stomach contents in Ctenodiscus crispatus and the porcellanasterids Eremicaster tenebrarius and Thoracaster magnus, concluded that they ingest mud directly, and stated that 'if the species of sea stars had fed by means of water currents generated by ciliary movements of the epithelial cells ...., their stomachs would have contained not benthic ooze but rather a more or less finely filtered detritus, (but) this fact was not so' (translation by D. E. Howard). Our quantitative analysis of stomach contents in C. crispatus is thus in agreement with the observations by Sokolova (1958) and Carey (1972).

All of the above observations are consistent with our previous suggestion that Ctenodiscus crispatus, and now, the Porcellanasteridae, non-selectively ingest bulk sediment and occasionally other macrofauna living in it. If even the surface deposits of stratified deepsea sediments are organically poor, a benthic feeder would gain little by relying exclusively on ciliary currents to gradually provide such materials as food, and in fact we have observed that the currents produced by C. crispatus entrain few particles from the sediment surface. Indeed, Sokolova (1958) specifically excluded this feeding mode from those that she considered adapted for subsistence on organically poor abyssal 
deposits. It is more likely that infaunal, mud-swallowing asteroids periodically ascend to the surface, ingest bulk sediment there, and retire to an irrigated (= oxygenated) burrow to digest the meal. The reduction in number of cribriform organs and increase in their
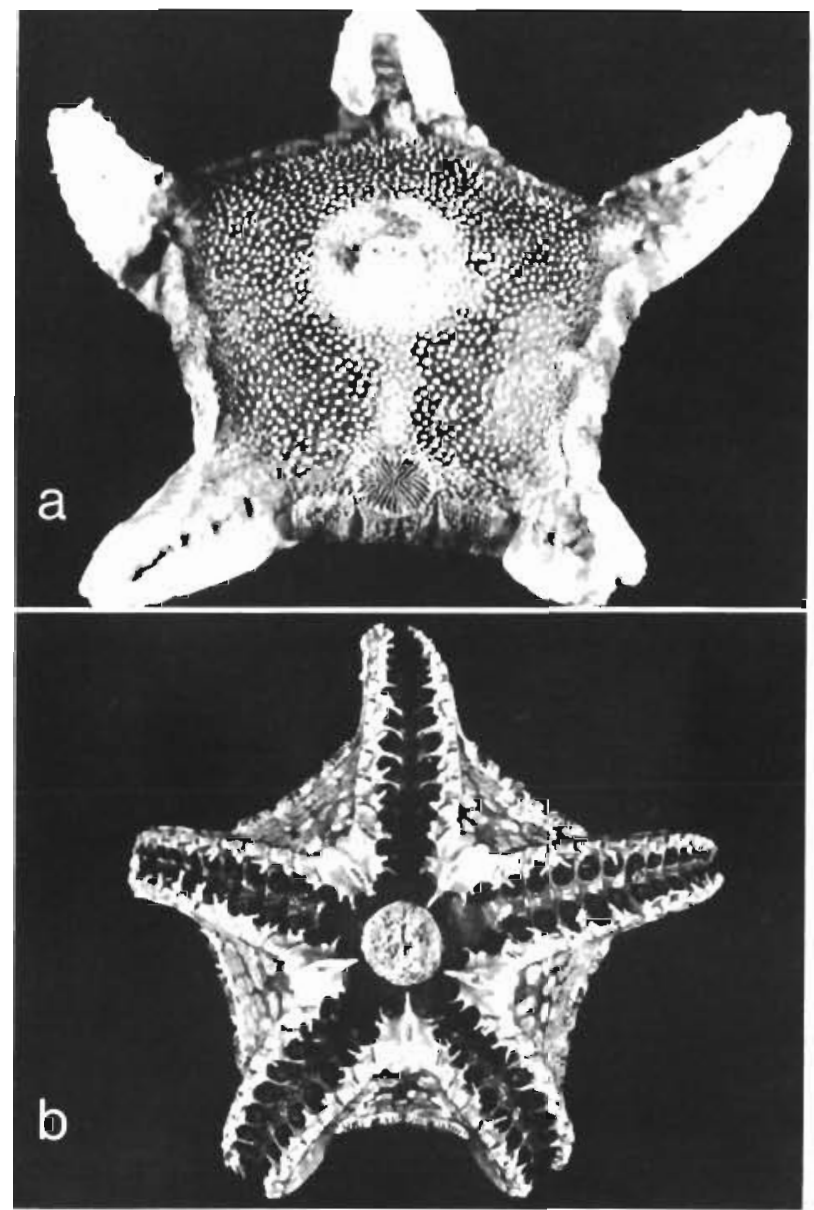

Fig. 12. Eremicaster sp. Two specumens from University of Maine Station 51; 57 22.6'S, 26 34.0'W; 26 May 1975; 2249-2403 m. (a) Aboral surface and marginal plates, as well as cribriform organs of one interradius, with madreporite, in specimen where $\mathrm{R}=19 \mathrm{~mm}, \mathrm{r}=9 \mathrm{~mm}$, (b) Oral surface of specimen in which $R=26 \mathrm{~mm}, r=12 \mathrm{~mm}$. Note lack of channels in the oral interradial area

complexity in porcellanasterids such as Eremicaster (Fig. 12a) relative to $C$. crispatus should retain a large current flow. The absence of fascioles on the oral surface (Fig. 12b), which in C. crispatus convey any resuspended particles directly into the ambulacra, is further evidence that feeding on current-entrained particles is not the rule in these asteroids.

The enormously expansible stomach in Ctenodiscus crispatus may be an adaptation to the low (and refractory) organic matter which some populations encounter. Rather than sieving for the organically rich- est fine fraction in such sediments, the animal likely simply increases the total amount that it ingests, and Sokolova (1958) has noted that specimens from organically poor substrates contain proportionally more sediment than do those from richer habitats.

Although the initial interests of physiologists in deep-sea animals concerned adaptations to high hydrostatic pressure and constant low temperature, increasing attention is being paid to the chronically low availability of food and its biological manifestations (low protein content of tissues, low metabolic rates, low levels of activity, etc.). Continuous food scarcity is now viewed as a major determinant of adaptive strategies in deep-sea animals (e.g. Somero et al., in press). If the low level and refractory nature of particulate organic matter in deep-sea sediments (Sanders et al., 1965) is indeed a limiting factor for benthic invertebrates there (e.g., Sokolova, 1959, 1972; Rex et al., 1979; for consideration of asteroids, see Carey, 1972), then the nutritional importance of dissolved primary amines and other organic molecules in deeper populations of Ctenodiscus crispatus and in other goniopectinid and porcellanasterid sea stars such as Eremicaster may be relatively enhanced, since amino acid concentrations in deep-sea sediments (Henrichs and Farrington, 1979) are similar to those in the present study. This of course assumes that deep-sea asteroids have amino acid transport systems with kinetic parameters comparable to those seen in $C$. crispatus in the present study. (The shallow-water asteroid Echinaster also shows a net uptake of primary amines from concentrations below $1 \mu \mathrm{M}$; Ferguson, 1980). Unfortunately, no data on amino acid transport by truly deep-sea asteroids are available, although the rate of glucose uptake by the sea star Plutonaster from a depth of $1800 \mathrm{~m}$ (Southward and Southward, 1972a) is considerably greater than that in the shallow-water polychaete Nereis diversicolor (Ahearn and Gomme, 1975) and similar to that in a number of deep-sea and shallow-water pogonophorans (Southward and Southward, 1972b). These admittedly tenuous comparisons at least suggest that the general slowing of metabolic processes in the deep sea may not extend to the transport of exogenous organic substrates by benthic invertebrates.

The phanerozonian sea stars are well-adapted to life in soft sediments. The ingestion of these sediments provides a stable and organically complex source of nutrition, which in Ctenodiscus crispatus is manifested as a less strongly seasonal reproduction than in all other asteroids studied to date and in a high genetic variability in this population (Shick et al., in press). Aseasonal reproduction and large amounts of genetic variation likewise are common in other omnivorous, deep-sea echinoderms and seem related to their gener- 
ally small size, limited vagility, and especially the stability and organic complexity of their diets, as demonstrated in the present study of $C$. crispatus.

Acknowledgements. This work has been aided by numerous people, whose efforts we greatly appreciate: R. G. and B. D. Gustafson, A. Lcamy, E. F. Lowe, W. F. Taylor, and other friends occasionally pressed into service, for shipboard assistance; the Ira C. Darling Center of the University of Maine for use of the R. V 'Lee', and especially boat captains F. Bowers and M. Dunn, for their cooperation; H. H. DeWitt and D. Schnitker for the loan of collecting gear; K. Melansnn for aid in particle size determinations and computer analyses; $G$. Miekina and S. Tyler for assistance with and discussions about electron microscopy: D. E. Howard for translations from the Russian; and B. L. Bayne, R. C. Newell, and A. J. and E. C. Southward for critically reading the manuscript. The research was supported by US National Science Foundation grant PCM76-81467 (Regulatory Biology) to J. M. Shick and J H. Dearborn. Some technical support and the Eremicaster material were obtained under NSF grants OPP74-08565 A01 and DPP76-23043 (Polar Programs) to H. H. DeWitt, J. D. McCleave, and J. H. Dearborn

\section{LITERATURE CITED}

A.hearn, G. A., Gomme, J. (1975). Transport of exogenous Dglucose by the integument of a polychaete worm (Nereis diversicolor Müller). J. exp. Biol. 62: 243-264

Ahearn, G. A., Townsley, S. J. (1975). Integumentary amino acid transport and metabolism in the apodous sea cucumber, Chiridota rigida. J. exp. Biol. 62: 733-752

Alton, M. S. (1966). Bathymetric distribution of sea stars (Asteroidea) off the northern Oregon coast. J. Fish. Res. Bd Can. 23: 1673-1714

Bayne, B. L., Widdows, J., Thompson, R. J. (1976). Physiological integrations. In: Bayne, B. L. (ed.) Marine mussels: Their ecology and physiology. Cambridge University Press, Cambridge, pp. 261-291

Byers, S. C., Mills, E. L., Stewart, P. L. (1978). A comparison of methods of determining organic carbon in marine sediments, with suggestions for a standard method. Hydrobiologia 58: 43-47

Calow, P. (1977). Ecology, evolution and energetics: a study in metabolic adaptation. In: Macfayden, A. (ed.) Advances in ecological research, Vol. 10. Academic Press, New York, pp. 1-62

Carey, A. G., Jr (1972). Food sources of sublittoral, bathyal and abyssal asteroids in the northeast Pacific Ocean. Ophelia 10: $35-47$

Cavanaugh, G. M. (ed.) (1956). Formulae and methods VI of the Marine Biological Laboratory chemical room, Marine Biological Laboratory, Woods Hole, Massachusetts

Christensen, A. M. (1970). Feeding biology of the sea-star Astropecten irregularis Pennant. Ophelia 8: 1-134

Clifton, H. E., Thompson, J. K. (1978). Macaronichnus segregatis: a feeding structure of shallow marine polychaetes. J. sedim. Petrol. 48: 1293-1302

Costopulos, J. J., Stephens, G. C., Wright, S. H. (1979). Uptake of amino acids by marine polychaetes under anoxic conditions. Biol. Bull mar biol. Lab., Woods Hole 157: 434-444

Crowe, J. H., Dickson, K. A., Otto, J. L., Cólon, R. D., Farley, K. K. (1977). Uptake of amino acids by the mussel, Modiolus demissus. J. exp. Zool. 202: 323-332
Dale, N. G. (1974). Bacteria in intertidal sediments: factors related to their distribution. Limnol. Oceanogr. 19 509-518

Degens, E. T. (1970). Molecular nature of nitrogenous compounds in sea water and recent marine sediments. In: Hood, D. W. (ed.) Symposium on organic matter in natural waters. Institute of Marine Science, University of Alaska, College, Alaska, pp. 77-106

Dejours, P. (1975). Principles of comparative respiratory physiology, North-Holland Publishing Company, Amsterdam

Edwards, K. C. (1980). Morphology and feeding biology of Ctenodiscus crispatus (Echinodermata: Asteroidea). M. S thesis, University of Maine, Orono, Maine USA

Fenchel, T., Koefoed, L. H., Lappalainen, A. (1975). Particle size selection of two deposit feeders: the amphipod Corophium volutator and the prosobranch Hydrobia ulvae. Mar Biol. 30: 119-128

Ferguson, J. C. (1967). An autoradiographic study of the utilization of free exogenous amino acids by starfishes Biol. Bull. mar biol. Lab., Woods Hole 133: 317-329

Ferguson, J. C. (1970). An autoradiographic study of the translocation and utilization of amino acids by starfish Biol. Bull. mar biol. Lab., Woods Hole 138: 14-25

Ferguson, J. C. (1980). Fluxes of dissolved amino acids between sea water and Echinaster. Comp. Biochem. Physiol 65 A: 291-295

Fisher, W K. (1911). Asteroidea of the North Pacific and adjacent waters. Part I. Phanerozonia and Spinulosa. Bull U.S. natn. Mus. 76: 1-419

Folk, R. L. (1974). Petrology of sedimentary rocks, Hemphill's Austin, Texas

Gislén, I (1924). Echinoderm studıes. Zool. Bidr. Uppsala 9 $1-316$

Grainger, E. H. (1966). Sea stars (Echinodermata: Asteroidea) of arctic North America. Bull. Fish. Res. Bd Can. 152: 1-70

Grossert, J. S., Mathiaparanam, P., Hebb, G. D., Price, P., Campbell, I. M. (1973). The sterols of the echinoderm, Ctenodiscus crispatus (Retzius). Experientia 29: 258-259

Hargrave, B. T (1972). Aerobic decomposition of sediment and detritus as a function of particle surface area and organic content. Limnol. Oceanogr 17: 583-596

Hauksson, E. (1979). Feeding biology of Stichopus tremulus, a deposit-feeding holothurian. Sarsia 64: 155-160

Henrichs, S. M., Farrington, J. W. (1979). Amino acids in interstitial waters of marine sediments. Nature, Lond. 279 : 319-322

Holland, N. D., Jesperson, A. (1973). The fine structure of the fertilization membrane of the feather star Comanthus japonica (Echinodermata: Crinoidea). Tissue \& Cell 5: 209-214

Holland, N. D., Nealson, K. H. (1978). The fine structure of the echinoderm cuticle and the subcuticular bacteria of echinoderms. Acta Zool. 59: 169-185

Holme, N. A. (1964). Methods of sampling the benthos. Adv mar Biol. 2: 171-260

Hyman, L. H. (1955). The invertebrates: Echinodermata, the coelomate Bilateria, Vol. IV, McGraw-Hill Inc, New York

Johansen, K., Petersen, J. A. (1971). Gas exchange and active ventilation in a starfish, Pteraster tesselatus. $Z$. vergl. Physiol. 71 365-381

Johnson, R. G. (1974). Particulate matter at the sedimentwater interface in coastal environments. J. mar Res. 32: 313-330

Jørgensen, C. B. (1966). Biology of suspension feeding, Pergamon Press Inc. New York

Jergensen. C. B. (1975). Comparative physiology of suspension feeding. A. Rev. Physiol. 37.57-79 
Jorgensen, C. B. (1976). August Pütter, August Krogh, and modern ideas on the use of dissolved organic matter in aquatic environments. B1ol. Rev. 51. 291-328

Kenk, R. (1944). Ecological observations on two Puerto Rican echinoderms, Mellita lata and Astropecten marginatus. Biol Bull. mar biol. Lab., Woods Hole 87: 177-187

Levinton, J. S. (1977). Ecology of shallow water depositfeeding communities Quisset Harbor, Massachusetts. In: Coull, B.C. (ed.) Ecology of marine benthos. University of South Carolina Press, Columbia, South Carolina, pp. 191-227

Lieberkind, I. (1935). Asteroidea. I. Porcellanasterıdae. Dan. Ingolf-Exped. 4: 1-37

Longbottom, M. R. (1970). The distribution of Arenicola marina (L.) with particular reference to the effects of particle size and organic matter of sediments. J. exp. mar Biol. Ecol. 5: 138-157

Madsen, F. J (1961a). The Porcellanasteridae. A monographic revision of an abyssal group of sea stars. Galathea Rep. 4: 33-174

Madsen, F. J. (1961b). On the zoogeography and origin of the abyssal fauna in view of the knowledge of the Porcellanasteridae. Galathea Rep. 4: 177-218

Mangum, C. P. (1977). The analysis of oxygen uptake and transport in different kinds of animals. J. exp. mar Biol. Ecol. 27: 125-140

Mangum, C. P., Burnett, L. E. (1975). The extraction of oxygen by estuarine invertebrates. In: Vernberg. F. J. (ed.) Physiological ecology of estuarine organisms. University of South Carolina Press, Columbia, South Carolina, pp. $147-163$

Mortensen, Th. (1927). Handbook of the echinoderms of the British Isles, Oxford University Press, Edinburgh

Muscatine, L., D'Elia, C. F. (1978). The uptake, retention and release of ammonium by reef corals. Limnol. Oceanogr 23: $725-734$

Newell, R. C. (1979). Biology of intertidal animals, 3rd ed., Marine Ecological Surveys Ltd., Faversham, Kent, United Kingdom

North, B. B. (1975). Primary amines in California coastal waters: utilization by phytoplankton. Limnol. Oceanogr 20: $20-27$

Pearse, J. S., Pearse, V B. (1973). Removal of glycine from solution by the sea urchin Strongylocentrotus purpuratus. Mar. Biol. 19: 281-284

Revsbech, N. P., Sorensen, J., Blackburn, T. H., Lomholt, J. P, (1980). Distribution of oxygen in marine sediments measured with microelectrodes. Limnol. Oceanogr 25: 403-411

Rex, M. A., Van Umersen, C. A., Turner, R. D. (1979). Reproductive pattern in the abyssal snail Benthonella tenella (Jeffreys). In: Stancyk, S. E. (ed.) Reproductive ecology of marine invertebrates. University of South Carolina Press, Columbia, South Carolina, pp. 173-188

Rhoads, D. C. (1974). Organism-sediment relations on the muddy sea floor. Oceanogr. mar. Biol. A. Rev. 12: 263-300

Rhoads, D. C., Young, D. K. (1970). The influence of depositfeeding organisms on sediment stability and community trophic structure. J. mar Res. 28: 150-178

Rhoads, D. C., Young, D. K. (1971). Animal-sediment relations in Cape Cod Bay, Massachusetts. II. Reworking by Molpadia oolitica (Holothuroidea). Mar. Biol. 11: 255-261

Sabatini, D. D., Bensch, K., Barrnett, R. J. (1963). Cytochemistry and electron microscopy. The preservation of cellular structure and enzymatic activity by aldehyde fixation. $J$. Cell. Biol. 17: 19-58

Sanders, H. L., Hessler, R. R., Hampson, G. R. (1965). An introduction to the study of deep-sea benthic faunal assemblages along the Gay Head-Bermuda transect. Deep Sea Res. 12: 845-867

Self, R. F. L., Jumars, P. A. (1978). New resource axes for deposit feeders? J. mar. Res. 36: 627-641

Sepers, A. B. J. (1977). The utilization of dissolved organic compounds in aquatic environments. Hydrobiologıa 52: $39-54$

Sheldon, R. W., Parsons, T R. (1967). A practical manual on the use of the Coulter Counter in marine research, Coulter Electronics Sales Co., Toronto, Canada

Shick, J. M. (1975). Uptake and utilization of dissolved glycine by Aurelia aurita scyphistomae: temperature effects on the uptake process; nutritional role of dissolved amino acids. Biol. Bull. mar. biol. Lab., Woods Hole 148: 117-140

Shick, J. M. (1976). Physiological and behavioral responses to hypoxia and hydrogen sulfide in the infaunal asteroid Ctenodiscus crispatus. Mar Biol. 37: 279-289

Shick, J. M., Taylor, W. F., Lamb, A. N. (in press). Reproduction and genetic variation in the deposit-feeding sea star Ctenodiscus crispatus. Mar Biol.

Siebers, D. (1979). Transintegumentary uptake of dissolved amino acids in the sea star Asterias rubens. A reassessment of its nutritional role with special reference to the significance of heterotrophic bacteria. Mar Ecol. Prog. Ser. 1: 169-177

Sladen, W P. (1883). The Asteroidea of H. M. S. 'Challenger Expedition - Part II. J. Linn Soc. Zool. 17: 214-269

Sokal, R. R., Rohlf, F. J. (1969). Biometry, the principles and practice of statistics in biological research, W. H. Freeman \& Company, San Francisco

Sokolova, M. N. (1958). Nutrition of deepwater benthic invertebrate detritus-feeders (Russ.). Trudý Inst. Okeanol $27 \cdot 123-153$

Sokolova, M. N. (1959). On the distribution of deep-water bottom animals in relation to their feeding habits and the character of sedimentation. Deep Sea Res. 6: 1-4

Sokolova, M. N. (1972). Trophic structure of deep-sea macrobenthos. Mar. Biol, 16: 1-12

Somero, G. N., Siebenaller, J. F., Hochachka, P. W (in press) Physiological and biochemical adaptations of deep-sea animals. In: Rowe, G. T (ed.) The sea, Vol. 8. Wiley-Interscience, New York

Southward, A. J., Southward, E. C. (1972a). Observations on the role of dissolved organic compounds in the nutrition of binthic invertebrates. II. Uptake by other animals living in the same habitat as pogonophores, and by some littoral Polychaeta. Sarsia 48: 61-70

Southward, A. J., Southward, E. C. (1972b). Observations on the role of dissolved organic compounds in the nutrition of benthic invertebrates. III. Uptake in relation to organic content of the habitat. Sarsia 50: 29-46

Southward, A. J., Southward, E. C. (1980). The significance of dissolved organic compounds in the nutrition of Siboglinum ekmani and other small species of Pogonophora. J. mar. biol. Ass. U.K. 60: 1005-1034

Spencer, W. K., Wright, C. W. (1966). Asterozoans. In: Moore, R. C. (ed.) Treatise on invertebrate paleontology, Part U, Echinodermata, 3. Asterozoa-Echinozod 1: 4-107

Stephens, G. C. (1975). Uptake of naturally occurring primary amines by marine annelids. Biol. Bull. mar. biol. Lab., Woods Hole 149: 397-407

Stephens, G. C., Volk, M. J., Wright, S. H., Backlund, P. S. (1978). Transepidermal accumulation of naturally occurring amino acids in the sand dollar, Dendraster excentricus. Biol. Bull. mar. biol. Lab., Woods Hole 154 : 335-347 Stewart, M. G. (1979). Absorption of dissolved organic nu- 
trients by marine invertebrates. Oceanogr mar Biol. A. Rev. 17: 163-192

Summers, R. G., Hylander, B. L., Colwin, L. H., Colwin, A. L (1975). The functional anatomy of the echinoderm spermatozoan and its interaction with the eqg at fertilization. Am. Zool. 15: 523-551

Taghon, G. L., Self, R. F. L., Jumars, P. A. (1978). Predicting particle selection by deposit feeders: a model and its implications. Limnol. Oceanogr. 23: 752-759

Turner, R. L. (1976). Sexual difference in latent period of spawning following injection of the hormone 1-methyladenine in Echinaster (Echinodermata: Asteroidea). Gen. comp. Endocr 28: 109-112

Turner, R. L., Dearborn, J. H. (1972). Skeletal morphology of the mud star Ctenodiscus crispatus (Echinodermata Asteroidea). J. Morphol. 138: 239-262

Verrill, A. E. (1914). Monograph of the shallow-water star- fishes of the North Pacific coast from the Arctic Ocean to California. Harriman Alaska Ser. 14: 1-408

Whitlatch, R. B. (1974). Food-resource partitionıng in the deposit-feeding polychaete Pectinaria gouldii. Biol. Bull. mar biol. Lab., Woods Hole 147: 227-235

Wilkinson, G. N. (1961). Statistical estimations in enzyme kinetics. Biochem. J. 80: 324-334

Winne, D. (1973). Unstirred layer, source of biased Michaelis constant in membrane transport. Biochum. biophys. Acta 298: $27-31$

Wright, S. H. (1979). Effect of activity of Jateral cilia on transport of amino acids in gills of Mytilus californianus. J. exp. Zool. 209: 209-220

Wright, S. H., Stephens, G. C. (1978). Removal of amino acid during a single passage of water across the gill of marine mussels. J. exp. Zool. 205: 337-351

This paper was presented by Dr A. J. Southward; it was accepted for printing on March 2, 1981 